\title{
Article \\ Effect of Impact Velocity, Flooring Material, and Trochanteric Soft-Tissue Quality on Acetabular Fracture during a Sideways Fall: A Parametric Finite Element Approach
}

\author{
Shahab Khakpour 1,*(D), Petri Tanska ${ }^{2}$, Amir Esrafilian ${ }^{2} \mathbb{D}$, Mika E. Mononen ${ }^{2}$, Simo Saarakkala ${ }^{1,3,4}$ (D), \\ Rami K. Korhonen ${ }^{2}$ and Timo Jämsä ${ }^{1,3,4}$ D \\ 1 Research Unit of Medical Imaging, Physics, and Technology, University of Oulu, 90570 Oulu, Finland; \\ Simo.saarakkala@oulu.fi (S.S.); Timo.jamsa@oulu.fi (T.J.) \\ 2 Department of Applied Physics, University of Eastern Finland, 70211 Kuopio, Finland; \\ Petri.tanska@uef.fi (P.T.); Amir.esrafilian@uef.fi (A.E.); Mika.mononen@uef.fi (M.E.M.); \\ Rami.korhonen@uef.fi (R.K.K.) \\ 3 Medical Research Center, University of Oulu and Oulu University Hospital, 90220 Oulu, Finland \\ 4 Diagnostic Radiology, Oulu University Hospital, 90220 Oulu, Finland \\ * Correspondence: Shahab.khakpour@oulu.fi; Tel.: +358-465645527
}

check for

updates

Citation: Khakpour, S.; Tanska, P.; Esrafilian, A.; Mononen, M.E.; Saarakkala, S.; Korhonen, R.K.; Jämsä, T. Effect of Impact Velocity, Flooring Material, and Trochanteric Soft-Tissue Quality on Acetabular Fracture during a Sideways Fall: A Parametric Finite Element Approach. Appl. Sci. 2021, 11, 365. https://doi.org/ 10.3390/app11010365

Received: 30 November 2020 Accepted: 25 December 2020 Published: 1 January 2021

Publisher's Note: MDPI stays neutral with regard to jurisdictional clai$\mathrm{ms}$ in published maps and institutional affiliations.

Copyright: (C) 2021 by the authors. Licensee MDPI, Basel, Switzerland. This article is an open access article distributed under the terms and conditions of the Creative Commons Attribution (CC BY) license (https:// creativecommons.org/licenses/by/ $4.0 /)$.
Featured Application: The results of this study can be used in designing prevention strategies for low-energy acetabular fractures. Also, it could help to cut the huge associated costs imposed on the health sector annually for managing acetabular fractures among the elderly population.

Abstract: A low-energy acetabular fracture, as a result of falling from standing height, is common among elderly patients and the number of cases is increasing rapidly in developed countries. Several biomechanical factors contribute to the incidence, severity, and type of acetabular fractures, such as body configuration at the impact moment or bone and soft-tissue quality. The current parametric study developed a comprehensive finite element model of the pelvic girdle and simple representation of the whole body and investigated the effects of impact velocity, conventional indoor/outdoor flooring material, and trochanteric soft-tissue stiffness on an acetabular fracture. Our results show that whereas the impact velocity has a substantial influence on the incidence and type of acetabular fracture, the effects of conventional flooring materials and trochanteric soft-tissue quality are not remarkable. It seems that other factors such as the quality of bone (healthy vs. osteoporotic), the thickness of trochanteric soft-tissue, and body configuration at the impact are more critical in the occurrence and type of the acetabular fracture. These results can be valuable in the prevention of acetabular fractures and the design of protective measures such as hip pads or novel flooring materials.

Keywords: low-energy acetabular fracture; impact velocity; flooring material; trochanteric soft tissue; finite element

\section{Introduction}

The incidence of low-energy fractures (e.g., falling from standing height) of the acetabulum has increased substantially (2.4-fold) in developed countries during recent decades [1-3]. Low-energy acetabular fractures are common among the geriatric population, and in most cases, they happen due to sideways falling [4,5], when the trochanteric soft tissue (TST) hits the ground and the impact force is transmitted through the femoral neck and head to the acetabulum [6,7]. Many factors such as bone and soft-tissue quality and body configuration during impact can affect the incidence, severity, and type of low-energy acetabular fractures $[2,8,9]$.

Owing to the higher incidence, the mechanism of proximal femur fractures resulting from low-energy falls has been studied widely [10-14]. Through different computational 
and experimental methods (e.g., mass-spring-damper system, inverse pendulum, pelvis release, and free-fall from standing height), the range of force applied to the femur and its corresponding impact velocities were reported as $1004-9990 \mathrm{~N}$ and $580-6070 \mathrm{~mm} / \mathrm{s}$, respectively [15]. Also, Robinovitch et al. [16] reported that the whole-body kinetic energy range varies from 160 to $387 \mathrm{~J}$ in backward and from 6 to $291 \mathrm{~J}$ in forward rotation during sideways falls. These force and impact velocity ranges do not necessarily imply the femoral fracture incidence. The typical range of the force that can cause a fracture in a femur during a sideways fall was reported from 1500 to $4000 \mathrm{~N}$ [15], although much smaller (573 N) [17] and much bigger forces (15,304 N) [18] have been reported. Even if the mortality rate of geriatric acetabular fractures is higher than that of proximal femur fracture [19], low-energy acetabular fractures have rarely been investigated [9,20]. Shim et al. [20] studied the acetabular fracture for standing and seating positions and reported the corresponding fracture loads as 3200 and 2300 N. Our previous study [9] showed that whereas the ground reaction force equal to $2600 \mathrm{~N}$ may cause a femoral fracture, it does not lead to acetabular fracture.

Whereas the effect of body configuration at the impact on the acetabular fracture was studied previously [9], the effect of other variables such as impact velocity $\left(\mathrm{V}_{\text {Impact }}\right)$, flooring material, and TST stiffness on low-energy acetabular fractures has remained underexplored. $\mathrm{V}_{\text {Impact }}$ is positively correlated with the body weight and height and, therefore, it can be speculated that taller and heavier individuals are at higher risk of fracture during a low-energy sideways fall [15]. Compliant flooring may decrease the incidence and severity of the injuries resulted from low-energy falls [21]. The role of flooring material in the prevention of bone fractures reflects in its shock-absorbent properties and ability in the attenuation of the force [22]. The effect of flooring material in low-energy fractures is somewhat unclear. Previous studies on low-energy fractures have indicated that compliant flooring might contribute to fracture prevention within the proximal femur (up to a 76.6\% reduction in the peak force in the femoral neck) [22-24], whereas it has also been suggested that changing the flooring material does not notably affect the impact force $[25,26]$. Some studies $[27,28]$ showed that novel compliant flooring systems can reduce the risk of proximal fracture substantially in comparison with conventional flooring materials. The role of TST thickness and mechanical properties in the attenuation and distribution of the impact load is critical. It was shown that a lower body mass index is correlated with an elevated risk of hip fracture [29,30] and Bouxsein et al. [31] suggested that the persons with a lower body mass index have a thinner TST too and their TST is unable to attenuate the impact force properly. Also, Majumder et al. investigated the effects of TST thickness and hip impact velocity on low-energy proximal femur fractures [32,33]. They stated that a decrease in TST thickness and an increase in the $\mathrm{V}_{\text {Impact }}$ are strongly correlated with an increase in the risk of proximal femur fracture. Whereas almost all of the studies agree that a higher $\mathrm{V}_{\text {Impact }}$ is associated with a higher risk of proximal femur fracture [15], there is debate on the role of TST thickness. Choi et al. [34] confirmed via an experimental study that neither stiffness nor dampening properties of the TST are associated with its thickness, as soft-tissue thickness remained almost constant among the young (19-30 years old) and elderly (65-81 years old) groups. In another study, Fleps et al. [35] concluded that TST thickness alone is not predictive of fracture. Reduction in thickness can result in an overall decrease in the absorption of impact-energy and dissipation capacity of the TST. Therefore, it can be speculated that the failure of the TST in the attenuation of the impact force is mostly attributed to the deterioration of its mechanical properties (not its thickness) due to aging.

The biomechanics of low-energy acetabular fracture has remained underexplored due to the uncertainties mentioned above (effect TST thickness vs. its stiffness and the difference between stiff and compliant conventional flooring materials) or to the lower incidence of acetabular fractures in comparison with the proximal fracture. Therefore, we aimed to assess the effect of impact velocity, flooring material, and trochanteric softtissue stiffness on the incidence, severity, and type of low-energy acetabular fracture. We performed a parametric study of these variables, changing $V_{\text {Impact, }}$ modeling different 
conventional flooring materials, and changing TST stiffness in sequential steps, using a detailed computed tomography (CT)-based finite element model of a median human pelvis-proximal femur-soft tissue complex with a simple representation of the whole body. The results of this study can be used in designing prevention strategies for low-energy acetabular fractures.

\section{Materials and Methods}

A detailed CT-based finite element model of a 50th percentile male patient from a large study database (mean age $72 \pm 12$ years) [3] with no known fracture history was established in LS-Dyna ${ }^{\circledR}$ (LSTC, Livermore, CA, USA). The model was constructed based on the median characteristics of the population [3] since this study aimed to investigate the variation of the incidence or type of acetabular fractures due to a change in the studied variables. Data regarding the falling conditions and mechanical properties of bone and soft tissues were derived from non-elderly subjects [15,36-38]. It was assumed that this model can provide an insight into the general mechanism of acetabular fracture which can be applicable for elderly people too.

A register-based study permit (number 220/2017) was granted by the Northern Ostrobothnia Hospital District, Oulu, Finland for this study.

\subsection{Three-Dimensional (3D) Model Preparation}

The cortical and trabecular bones of the femur and pelvic girdle were thresholded and segmented in Mimics ${ }^{\circledR}$ (version 21.0, Materialise Software, Belgium) using an abdominal CT image, collected at Oulu University Hospital (Philips, 110 kVp, 105 mAs, 453 slices with $0.5 \mathrm{~mm}$ thickness, resolution $0.75 \times 0.75 \mathrm{~mm}$ ). The location-dependent cortical thickness was obtained via a semi-automated slice-by-slice local thresholding procedure available in Mimics ${ }^{\circledR}$. The cortical thicknesses obtained, especially at the acetabulum (the thinnest cortical bone within the pelvis), were checked to make sure that they were in the typical reported range for the pelvic cortical bone $[39,40]$ (Appendix A, Figure A1). Since an abdominal CT image was used in this study, only the proximal part of the femur was reconstructed directly. The total length of the femoral shaft was estimated based on Khanal et al. [41], and the cortical bone of the femur was extended accordingly. The shape of the distal femur was not considered.

Since the CT image used was not acquired with a contrast agent, accurate segmentation of the cartilage and the interpubic disc was not possible and they were added using 3-matic ${ }^{\circledR}$ (version 13.0, Materialise Software, Belgium) software. The shapes of the cartilages and interpubic disc were derived from the Human Biodigital ${ }^{\circledR}$ online platform [42], considering the position of the reconstructed bony parts of the model. Also, the thicknesses of the femoral $(1.48 \mathrm{~mm})$ [43], acetabular $(1.31 \mathrm{~mm})$ [43] and sacroiliac cartilages $(3.50 \mathrm{~mm})$ [44], as well as the interpubic disc $(22.72 \mathrm{~mm})$ [38] were determined based on published data. Bones and cartilages were subtracted from the primary model to obtain a reconstructed CT-based soft-tissue geometry $[32,45]$. The soft tissue obtained was truncated in half and the impact side was retained to reduce the number of elements.

According to our previous work, body configuration during impact can substantially affect the strain magnitude and distribution within the acetabulum [9]. The pelvic and femoral orientations during CT imaging are distinctly different from those related to a sideways fall. In the supine position, the femur is externally rotated, and the pelvis remains almost in the neutral standing position, whereas during a sideways fall the femur is adducted and the pelvis is laterally tilted. Therefore, to resemble the postures of the femur and pelvis during a sideways fall and to obtain a proper deformed soft tissue, the femur was adducted and rotated internally using a quasi-static (implicit) simulation in ABAQUS $^{\circledR} /$ Standard (Appendix A, Figure A2a). The element size of the converged mesh was $4 \mathrm{~mm}$ (Appendix A, Figure A2b), comparable to the mesh size (3-10 mm) of Fleps et al. [13] for modeling the bulk soft tissue. The obtained mesh was exported to LS-Dyna as the soft tissue for the simulation of the impact (explicit). The body posture associated 
with the highest risk of acetabular fracture was selected based on our previous study [9]. The highest risk of acetabular fracture based on strain magnitude and concentration was obtained when the trunk flexion (sagittal plane), trunk tilt (coronal plane), femur internal rotation, and femur adduction angles were set to $0^{\circ}, 40^{\circ}, 15^{\circ}$, and $5^{\circ}$ (comparable to those used by Fleps et al. [13]), respectively (Figure 1a).

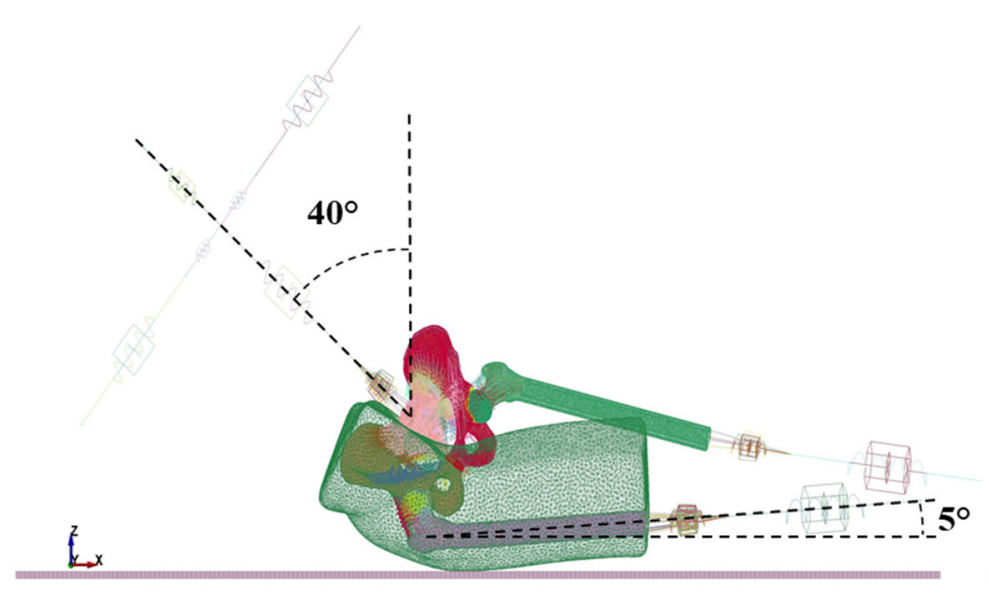

a

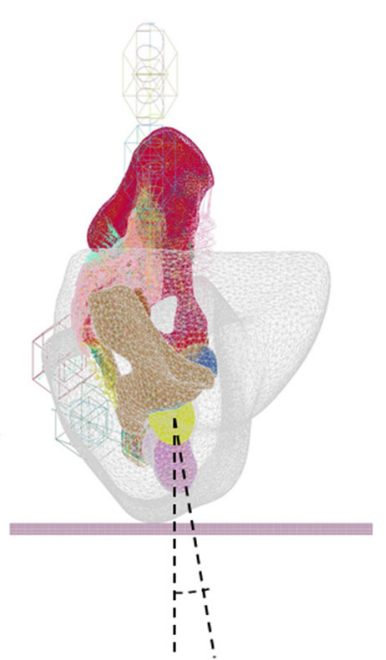

$15^{\circ}$

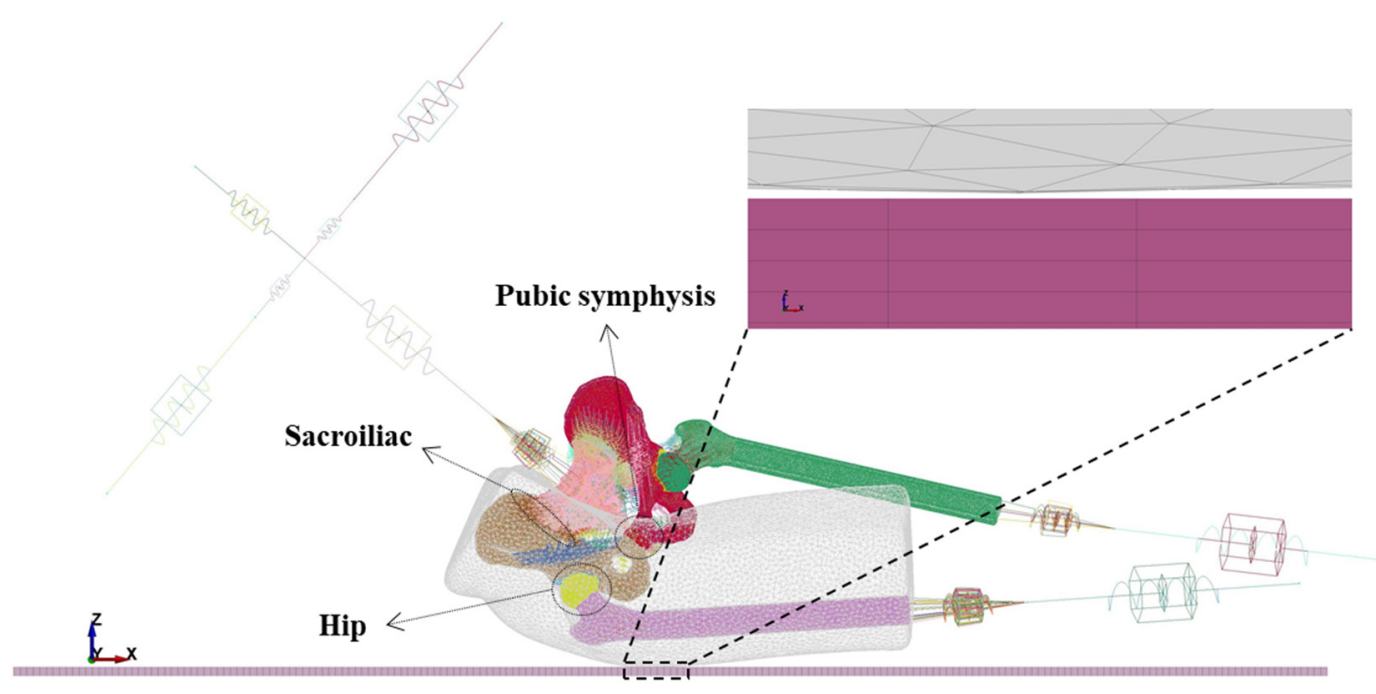

$\mathrm{b}$

Figure 1. (a) Body configuration angles at the impact; (b) location of the joints and the initial position of the model relative to the ground.

A lumped mass-spring-dashpot system was used to represent the whole body except the reconstructed parts (bony parts and soft tissues) (Appendix A, Figure A3a). The segments' masses and the locations of the lumped masses for the 50th percentile male model (weight: $76 \mathrm{~kg}$, height: $168.67 \mathrm{~cm}$ ) were adapted for the sideways fall body configuration, based on the work of Contini [46] (Appendix A, Figure A4, Table A1). The stiffness of connecting springs and damping coefficient of the dampers were obtained from Nigam and Malik [47], and Amirouche [48], respectively (Appendix A, Table A2). Since the soft 
tissue was truncated, the non-impact-side femur and the attached lumped masses-springsdashpots were rotated around the hip joint (adduction) to bring the distal femur toward the vicinity of the soft tissue (Figure 1a) in order to prevent the acceleration and impact of the non-impact-side femur to the soft tissue during the simulation.

The model obtained included femurs, sacrum, and left and right coxal bones, cartilages, ligaments, and the soft tissue covering them. After the mesh convergence study (Appendix A, Figure A3b), the selected mesh had 3,182,326 solid elements (element edge size ranging between 1.16 and $3.47 \mathrm{~mm}$ ). To increase accuracy, the cortical and trabecular bones of the impact-side pelvis (i.e., the region of interest) meshed with the quadratic 10-node tetrahedral solid elements while the other parts were modeled with linear 4-node tetrahedral solid elements to reduce the computational cost [13].

\subsection{Mechanical Properties of Tissues and Ground}

Cortical and trabecular bone mechanical properties are strain rate dependent [36]. Through an approach similar to Enns-Bray et al. [36] and by using the Fu-Chang foam material model (LS Dyna, MAT_083) (Appendix B, Table A5), they were modeled as isotropic, heterogenous, and viscoelastoplastic with different non-linear behaviors in tension and compression (Appendix B). According to Hansen et al. [49], the strain rate exerted on the body which can lead to bone failure during a traumatic event can be as big as $25 \mathrm{~s}^{-1}$. In this study, a wider range of strain rates $\left(0.008-30 \mathrm{~s}^{-1}\right)$ [36] was used to ensure coverage of all possible strain rates during falling. The cortical bone was assumed to be homogenous $\left(\rho=1.8 \mathrm{~g} / \mathrm{cm}^{3}\right)$ and trabecular bone density varied between 0.01 and $1.79 \mathrm{~g} / \mathrm{cm}^{3}$ (corresponding densities starting from marrow cavity to the density at the vicinity of the cortical bone). Densities were implemented to the mesh using the material mapping strategy available in Mimics ${ }^{\circledR}$ [45] in which bone grayscale values (i.e., Hounsfield units) in CT images were converted to the densities.

The soft tissue covering the greater trochanter, hemipelvis, and thigh is mostly made of muscle. Therefore, it was modeled as a single part in this study, and the hyperelastic model (LS Dyna, MAT_MOONEY-RIVLIN_RUBBER) and parameters proposed by Majumder et al. [45] were selected for the parametric studies of $V_{\text {Impact }}$ and flooring material effects on acetabular fracture (Appendix B, Table A5). Lim and Choi [50] considered TST as a viscoelastic material and studied the effect of aging on TST stiffness. In the current study, to examine the effect of TST quality (stiffness) changes due to aging on the acetabular fracture, a viscoelastic model (LS Dyna, MAT_061) was established. Muscle and adipose layers of TST have very distinct mechanical properties (bulk, short- and long-term shear modulus) [51]. Using an approach similar to Fleps et al. [13] for validating their proposed ballistic gel as a TST surrogate, the viscoelastic soft-tissue model was tailored based on values by Bandak et al. [51] and studied through a single element test [52] so that its compressive response would fall within the muscle and adipose tissue stress-strain response (Appendix B, Figure A7). The internal reaction force history within the joints resulted from the models proposed by Majumder et al. [45] and Fleps et al. [13] as the soft tissues are presented in Appendix B, Figure A8. The parameters obtained were assumed as the baseline (young subject) and were increased by $26 \%$ through four equidistances $(4 \times 6.5 \%)$, representing progressive stiffening of the TST by aging [50] for the parametric study (Appendix B, Table A5).

The articular and sacroiliac cartilages were assumed to be hyperelastic (LS Dyna, MAT_MOONEY-RIVLIN_RUBBER) [13], [45] (Appendix B, Table A5). The impact force is absorbed, dissipated, and transmitted between hemi-pelvises through the fibrous cartilage existing in the pubic symphysis [53]. Therefore the interpubic disc was modeled as a viscohyperelastic material (LS Dyna, MAT_HYPERELASTIC_RUBBER) [38] (Appendix B, Table A5).

Seven conventional flooring materials as well as rigid ground were considered to study the effect of flooring material on acetabular fracture: Ceramic tile (LS Dyna, MAT_JOHNSON_ HOLMQUIST_CERAMICS) [54], ethylene-vinyl acetate (EVA) foam protective mat (LS Dyna, 
MAT_OGDEN_RUBBER) [55], linoleum (LS Dyna, MAT_ELASTIC) [56], plywood (LS Dyna, MAT_WOOD_PINE) [57], agglomerated cork (LS Dyna, MAT_LOW_DENSITY_FOAM) [58], concrete (LS Dyna, MAT_CSCM_CONCRET) [59], and multi-layer asphalt pavement (LS Dyna, MAT_PIECEWISE_LINEAR_PLASTICITY) [60]. Rigid ground was used in $\mathrm{V}_{\text {Impact }}$ and TST quality simulations.

The ligaments were included using tension-only [44] springs (LS Dyna, MAT_SPRING_ NONLINEAR_ELASTIC) and their origin and insertion points were estimated based on the Human Biodigital ${ }^{\circledR}$ online platform [42]. The ligament stiffnesses were derived from literature [61-63] (Appendix A, Table A3). It was assumed that joints are kept in place by applying a small pre-load (pre-strained ligaments), that ligaments bear the tensile loads up to their yield points, and that further elongation results in the gradual reduction of the ligament load-bearing capacity (down to $0.1 \mathrm{~N}$ ) [63] (Appendix A). The muscle activation during a sideways fall is typically between relaxed (free-fall) and maximum-strength muscle force scenarios [64]. Due to the lack of data about the muscle recruitment patterns and the resulting forces during sideways falls, muscles were not included (relaxed free-fall scenario) in this study.

\subsection{Initial and Boundary Conditions}

To reduce calculation time, the model was brought close to the ground $(0.1 \mathrm{~mm})$ [45] (Appendix A, Figure A3a). Five impact velocities (580, 2140, 3170, 4310, and $6070 \mathrm{~mm} / \mathrm{s}$ ) were selected from the reported range for the sideways falls from standing height [15] and applied in the vertical direction (Figure 1, negative Z-axis) to study the effect of $V_{\text {Impact }}$ on acetabular fracture. To study the effects of flooring materials and TST stiffness on acetabular fracture, $V_{\text {Impact }}$ was set to $3170 \mathrm{~mm} / \mathrm{s}$ correspondings to a typical impact velocity in experimental fall studies in young people [65]. Also, gravitational acceleration $\left(9806 \mathrm{~mm} / \mathrm{s}^{2}\right)$ was applied to all moving parts.

All the nodes of in-contact parts (trabecular and cortical bone or cortical bone and soft tissues including cartilages) except at the hip joint, soft tissue-ground, and soft tissue-nonimpact-side femur, were tied in all degrees of freedom. The contact between the acetabular and femoral cartilages was assumed to be frictionless $[13,61]$. To establish the initial contact between the femoral and acetabular cartilages, the model was repositioned so that the maximum penetration at the contact areas (two regions at the anterior and posterior sides) remained smaller than $0.05 \mathrm{~mm}$. By using the shooting node logic of Ls Dyna, the possible contact force produced by the initial penetration was prohibited [66]. The contact between the soft tissue and the ground was assumed to be frictional (static and kinetic coefficients of friction set to 0.5 and 0.36 , respectively) $[45,67,68]$.

\subsection{Failure Criteria and Mechanisms}

During a traumatic event such as a sideways fall, bone failure initiates at the trabecular level and spreads to the cortical bone, ultimately resulting in a total bone failure $[13,45]$. Among different fracture criteria, the coupled criterion method by considering both critical stress (or strain) and energy criteria can predict crack initiation in a broad range of materials and configuration effectively $[69,70]$. Due to the lack of cadaveric test data, the aim of this study is not to predict the total bone fracture precisely, and the bone failure at the trabecular level (critical strain criterion) was the only failure criterion considered in the current study. The failure criteria used in this study were proposed by Enns-Bray et al. [36] and used by Fleps et al. [13] successfully to replicate the proximal femur fracture in simulated sideways fall cadaveric experiments. In brief, trabecular bone failure was assumed to occur through the onset of element softening, corresponding to the first and third principal strains of the St. Vernant-Green strain tensor being higher than $1.4 \%$ in tension and lower than $-2.0 \%$ in compression $[13,36]$.

It was assumed that after the element failure, tensile stress for both the cortical and trabecular bones is reduced exponentially to $10 \%$ of the ultimate stress [36]. In compression, the ultimate stress for the cortical bone was kept constant at post-failure, whereas for the 
trabecular bone, the collapse of the pores (softening) and densification of the trabeculae [71] was taken into account (Appendix B). Similar to Fleps et al. [13], element erosion at 20\% volume strains (sum of principle strains) was used to stabilize the model without any influence on the peak impact forces. All of these assumptions were used to produce stress-strain curves for different densities and strain rates as the material model inputs (Appendix B, Table A5).

\subsection{Simulations}

A total of 17 simulations (Table 1) were solved using LS-Dyna ${ }^{\circledR}$ (LSTC, Livermore, CA, USA). The duration of simulations was set to $100 \mathrm{~ms}$. This covered the peak impact forcetime (0.0005-0.015 s) [72] and was long enough to ensure the impact of energy propagation in the model $[13,73]$. The stable time step was $3.36 \times 10^{-8} \mathrm{~s}$. The automatic mass-scaling feature (LS Dyna, ENDMAS, maximum allowed added-mass percentage $=5 \%$ [74]) was used to reduce central processing unit (CPU) time and this resulted in a maximum increase in the total mass of $\sim 9 \times 10^{-4 \%}\left(\sim 8 \times 10^{-4} \mathrm{~kg}\right)$. The average calculation time per run while employing parallel processing (128 cores @ $2.5 \mathrm{GHz}, 240 \mathrm{GBs}$ of RAM) was $\sim 89 \mathrm{~h}$.

Table 1. Simulated variables.

\begin{tabular}{cc}
\hline Variable & Runs \\
\hline Impact velocity & $580,2140,3170 *, 4310,6070 \mathrm{~mm} / \mathrm{s}$ \\
\hline Conventional flooring material & $\begin{array}{c}\text { Rigid *, ceramic tile, ethylene-vinyl acetate, linoleum, } \\
\text { concrete, plywood, asphalt pavement, agglomerated cork }\end{array}$ \\
\hline TST stiffness & Baseline, $+6.5 \%,+13 \%,+19.5 \%,+26.0 \%$ \\
\hline F
\end{tabular}

* Constant value for simulations of other variables.

\section{Results}

The effects of $\mathrm{V}_{\text {Impact }}$, flooring material, and TST stiffness on the ground reaction force $(\mathrm{GRF})$, maximum joint internal reaction forces $\left(\mathrm{IRF}_{\max }\right)$ (the force transmitted through the in-contact parts of a joint) [13], and bone failure pattern by comparing the failed elements location with Judet and Letournel's classification [6], (Appendix A, Figure A5) are presented here. The bone failure was investigated around the time of $\mathrm{GRF}_{\max }\left(\mathrm{t}_{\max }\right)( \pm 0.005 \mathrm{~s})$.

\subsection{Ground Reaction Force}

$V_{\text {Impact }}$ : Increasing the $\mathrm{V}_{\text {Impact }}$ resulted in an increased GRF, shortened impact duration, and shortened $t_{\max }$ (Figure 2a). $\mathrm{GRF}_{\max }$ remained under $8800 \mathrm{~N}$ for the typical sideways fall impact velocities $\left(580,2140\right.$, and $3170 \mathrm{~mm} / \mathrm{s}$ ). A higher $\mathrm{GRF}_{\max }$ (up to 20,500 N) was observed for the higher impact velocities ( 4310 and $6070 \mathrm{~mm} / \mathrm{s}$ ) (Figure 2a). The area under the curve up to GRF $\mathrm{max}_{\max }\left(\mathrm{I}_{\mathrm{GRFmax}}\right)$ increased with increasing impact velocity, remaining in the range of $43.63-62.24 \mathrm{Ns}$ for $\mathrm{V}_{\text {Impact }}=580-3170 \mathrm{~mm} / \mathrm{s}$, but jumped up to substantially higher values $(91.38-111.94 \mathrm{Ns})$ for higher impact velocities $(4310$ and $6070 \mathrm{~mm} / \mathrm{s})$. Also, by increasing the $V_{\text {Impact }}$, the shape of the peak GRF region changed from the plateau to sharp (Figure 2a). The GRF responses were compared with similar previous studies in Appendix A, Figure A6 and Table A4.

Flooring material: the conventional flooring materials did not affect the $\mathrm{GRF}_{\max }, \mathrm{t}_{\max }$ or the shape of the GRF curve notably. For almost all of the flooring materials, $\mathrm{GRF}_{\max }$, $t_{\max }$, and impact duration were about $8800 \mathrm{~N}, 0.0155 \mathrm{~s}$, and $0.0375 \mathrm{~s}$, respectively. Only in the case of very compliant flooring material such as agglomerated cork, the GRF at the early-contact and after passing the GRF $\mathrm{max}_{\text {ax }}$ was slightly lower than for the stiffer surfaces.

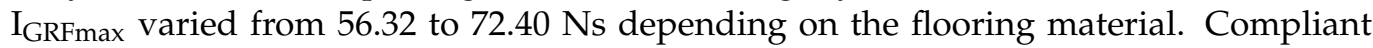
surfaces such as EVA foam and agglomerated cork had a greater $\mathrm{I}_{\text {GRFmax }}$ than stiff surfaces such as rigid ground and plywood (Figure $2 b$ ). 


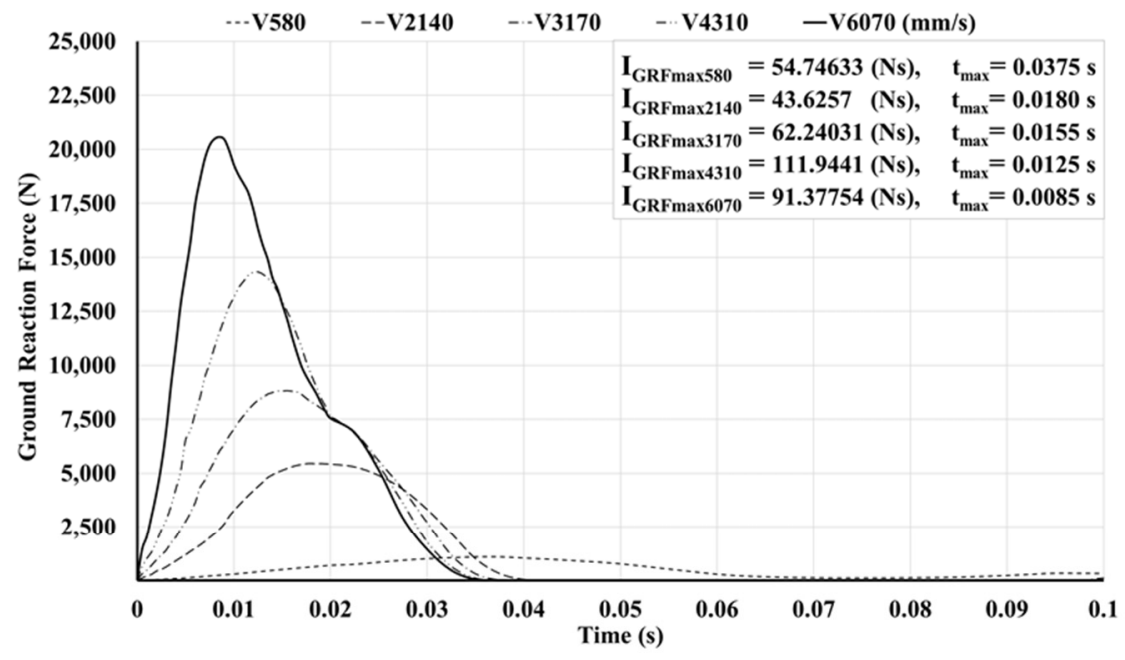

a

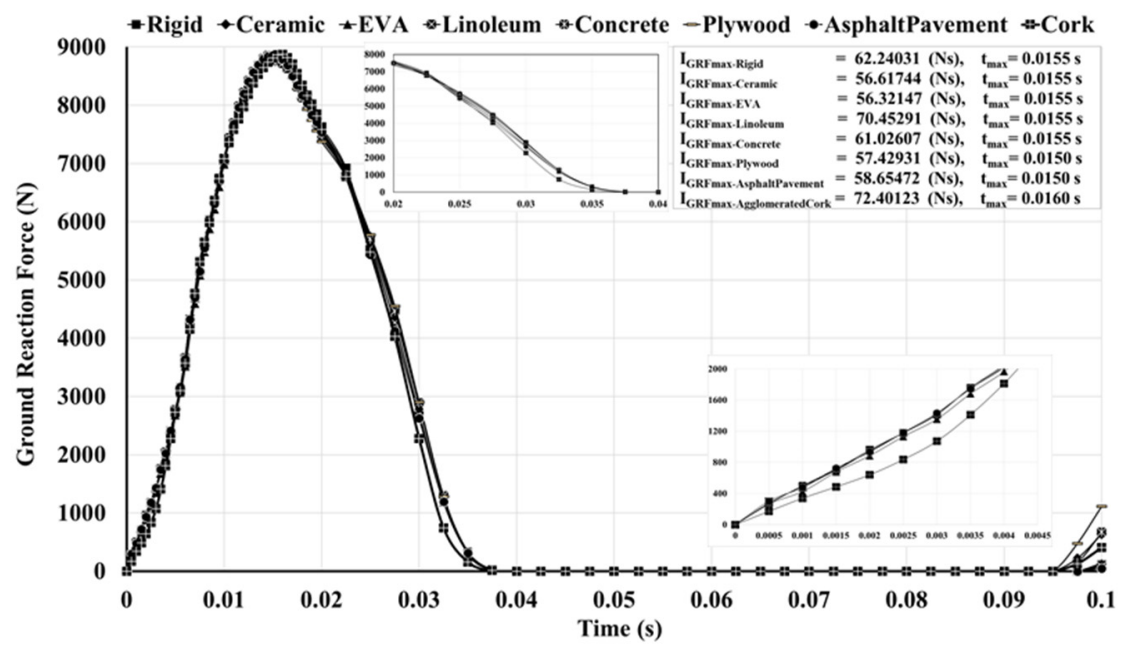

b

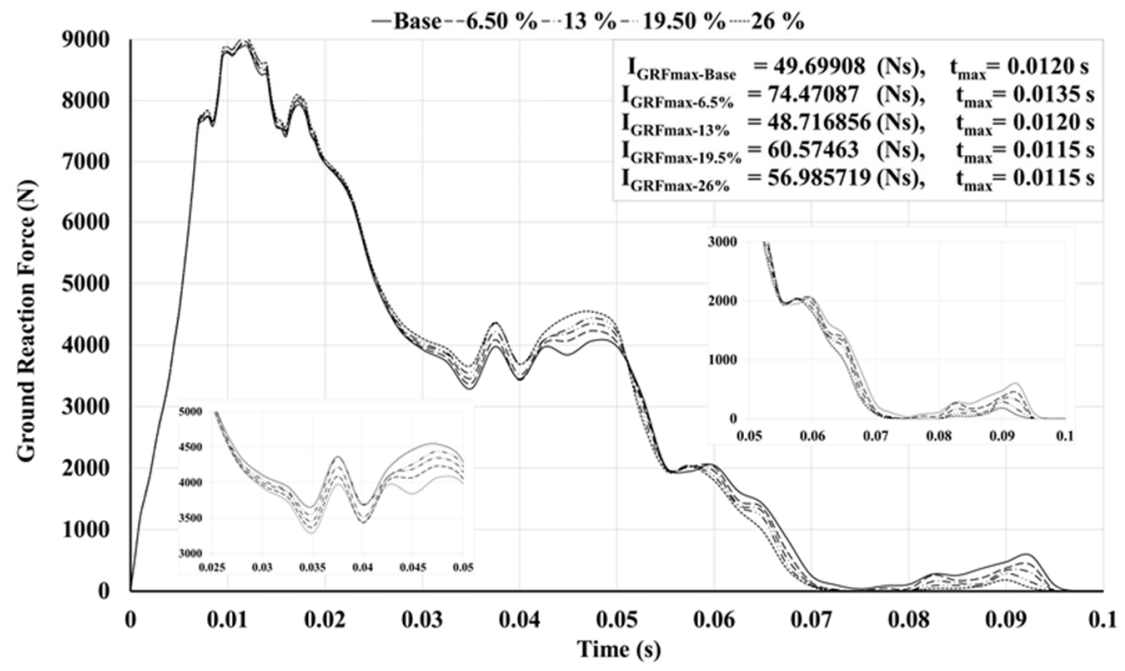

c

Figure 2. Ground reaction force: effect of (a) impact velocity; (b) flooring material; (c) trochanteric soft tissue (TST) stiffness.

TST stiffness: increasing the TST stiffness resulted in a slightly increased $\mathrm{GRF}_{\max }$, but it did not affect $t_{\max }$ and $\mathrm{I}_{\text {GRFmax }}$ substantially (Figure 2c). While the GRF remained almost 
constant for all TST stiffnesses before reaching the peak-impact region (0.007-0.02 s), a stiffer TST resulted in an increase and then a decrease in the GRF during the consecutive intervals $(0.025-0.05 \mathrm{~s}$ and $0.05-0.1 \mathrm{~s})$, respectively (Figure $2 \mathrm{c})$. For all TST stiffnesses, $\mathrm{t}_{\max }$ remained almost the same $(0.0115-0.0135 \mathrm{~s})$, and a stiffer TST did not cause a much greater $\mathrm{I}_{\mathrm{GRFmax}}$ in comparison with softer TST (74.47 vs. $\left.49.7 \mathrm{Ns}\right)$.

\subsection{Joints Internal Reaction Forces}

$V_{\text {Impact }}: \mathrm{IRF}_{\max }$, time-to-IRF $\max \left(\mathrm{t}_{\mathrm{IRFmax}}\right)$, and the curve shape for all joints (hip, pubic symphysis, and sacroiliac (Figure 1b)) were apparently dependent on $V_{\text {Impact }}$ and continued to change even after the impact phase. Increasing $V_{\text {Impact }}$ increased $I_{R F} F_{\max }$ and shortened $t_{\text {IRFmax }}$. At low impact velocities, the IRF response was noticeably smoother than the more oscillatory responses observed at high velocities (Figure $3 \mathrm{a}-\mathrm{c}$ ). Although the hip joint experienced a bigger $\mathrm{IRF}_{\max }$ than other joints, the $\mathrm{IRF}_{\max }$ in the hip joint was $20-30 \%$ of its corresponding $\mathrm{GRF}_{\max }$ (Figures 2a and 3a) and the remaining impact force transmitted through other joints and TST. Owing to the function of the pubic symphysis in shock absorption, its IRF was much more oscillatory than others (Figure 3b). In contrast to all other joints, the IRF in the sacroiliac joint did not decline considerably and remained at a high level (Figure 3c).

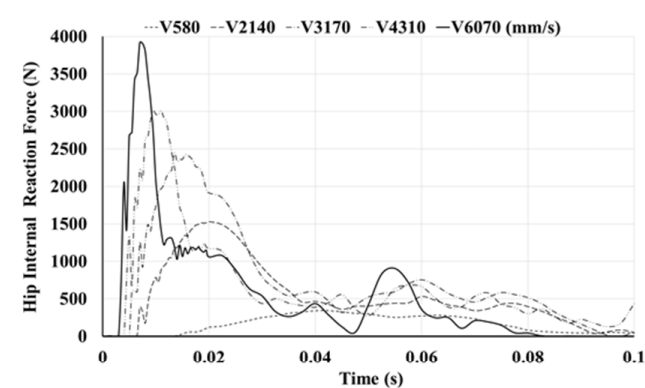

a

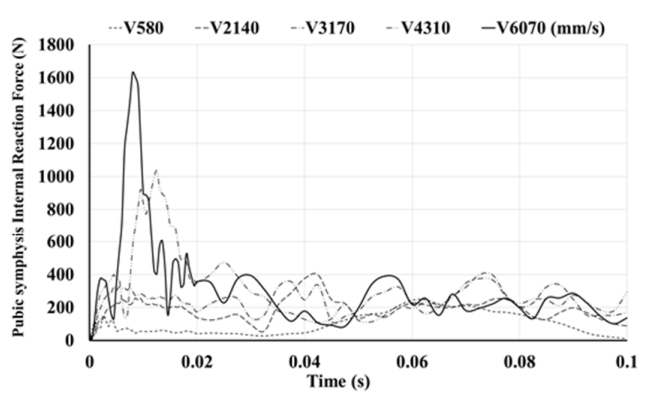

b

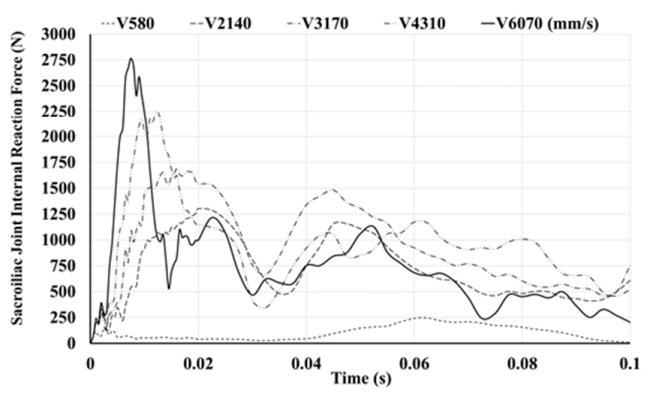

c

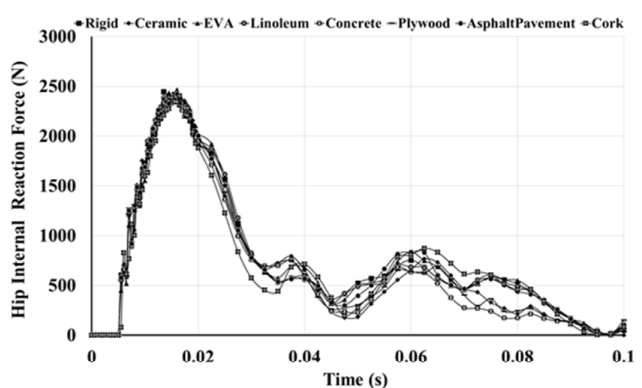

d

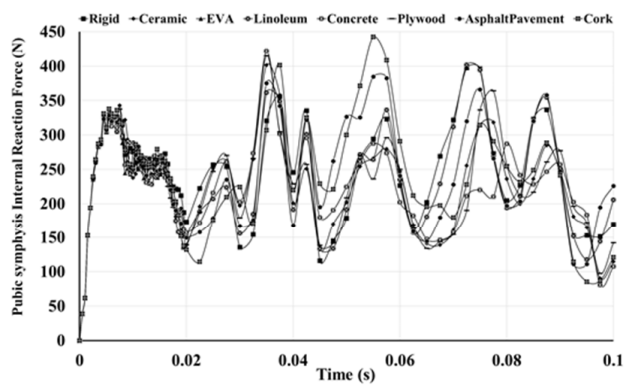

e

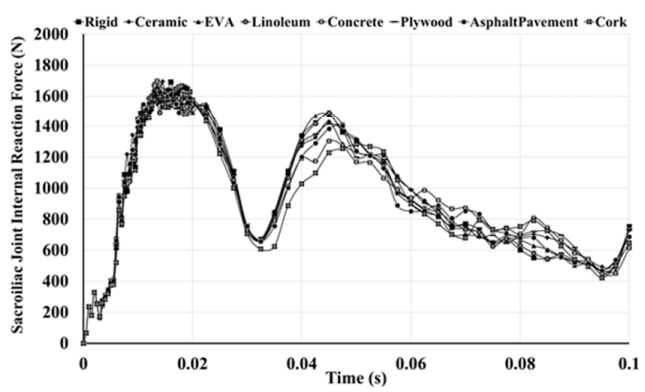

f

Figure 3. Internal reaction force: effect of (a) impact velocity at the hip; (b) impact velocity at the pubic symphysis; (c) impact velocity at the sacroiliac; (d) flooring material at the hip; (e) flooring material at the pubic symphysis; (f) flooring material at the sacroiliac joint. 
Flooring material: there was only a minor difference between stiff (rigid, concrete, asphalt pavement, ceramic tile, and plywood) and compliant (agglomerated cork, linoleum, and EVA foam) surfaces in terms of IRF $\max$ and $t_{I R F m a x}$ for all of the joints, except for the pubic symphysis which had several IRF peaks and a different $t_{\text {IRFmax }}$ (Figure $3 d-f$ ).

TST stiffness: increasing TST stiffness did not affect IRF max $_{\text {ax }}$ within the hip considerably (2476.74-2496.2 N), whereas increasing TST stiffness led to a higher IRF $\mathrm{max}_{\text {ax }}$ within the sacroiliac joint (Figure $4 \mathrm{a}-\mathrm{c}$ ). The $\mathrm{t}_{\text {IRFmax }}$ for all joints was almost independent of the TST stiffness and remained unchanged ( $\mathrm{t}_{\text {IRFmax-hip }} \approx 0.01$, $\mathrm{t}_{\text {IRFmax-pubicSymphysis }} \approx 0.0175$, and $t_{\text {IRFmax-sacroiliac }} \approx 0.0275$ ). For all TST stiffnesses, the $I_{R F}$ max within the hip joint was between 20 and $30 \%$ of the $\mathrm{GRF}_{\max }$. The $\mathrm{IRF}_{\max }$ was higher within the sacroiliac joint than in other joints. The general shape of the IRF response was similar for all TST stiffnesses, and only by passing the peak impact time $(\mathrm{t}>0.025 \mathrm{~s})$ could some delays in the following peak IRFs be seen for different TST stiffnesses, especially within the pubic symphysis and sacroiliac joints.

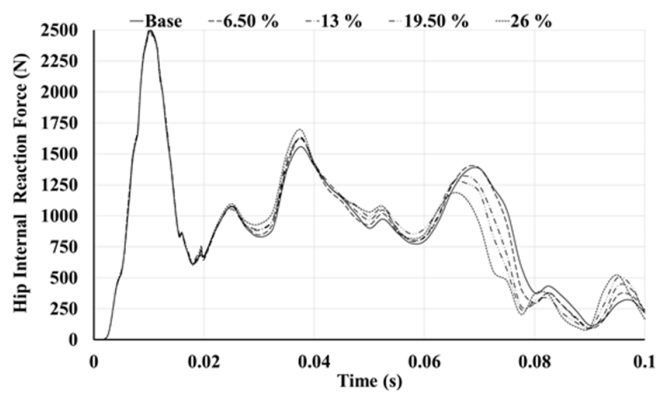

a

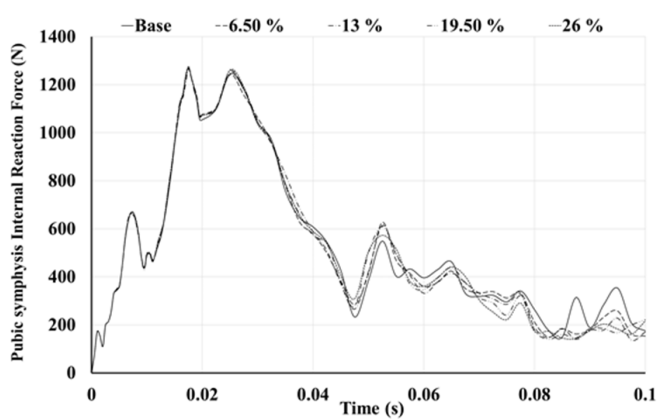

b

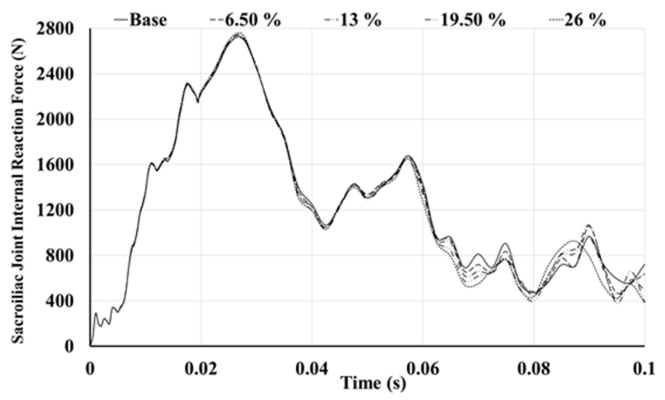

c

Figure 4. Internal reaction force: effect of (a) TST stiffness at the hip; (b) TST stiffness at the pubic symphysis; (c) TST stiffness at the sacroiliac joint. 


\subsection{Bone Failure Type}

$V_{\text {Impact }}$ for the very low $\mathrm{V}_{\text {Impact }}(580 \mathrm{~mm} / \mathrm{s})$ there was no clear compressive trabecular bone failure. By increasing $V_{\text {Impact }}$ from $2140 \mathrm{~mm} / \mathrm{s}$ to $4310 \mathrm{~mm} / \mathrm{s}$, the failure area located at the anterior acetabular wall expanded, and a further increase in $V_{\text {Impact }}$ up to $6070 \mathrm{~mm} / \mathrm{s}$ resulted in bone failure at the posterior acetabular wall, too. Also, compressive bone failure was observed at the ischiopubic ramus and inferior pubic ramus at the high $\mathrm{V}_{\text {Impact }}$ (4310 and $6070 \mathrm{~mm} / \mathrm{s}$ ). The results show that tensile failure was minor in comparison with compressive failure and was limited to some small areas at the cotyloid fossa, gluteus minimus attachment site, ischiopubic ramus, and ischial tuberosity (Figure 5).
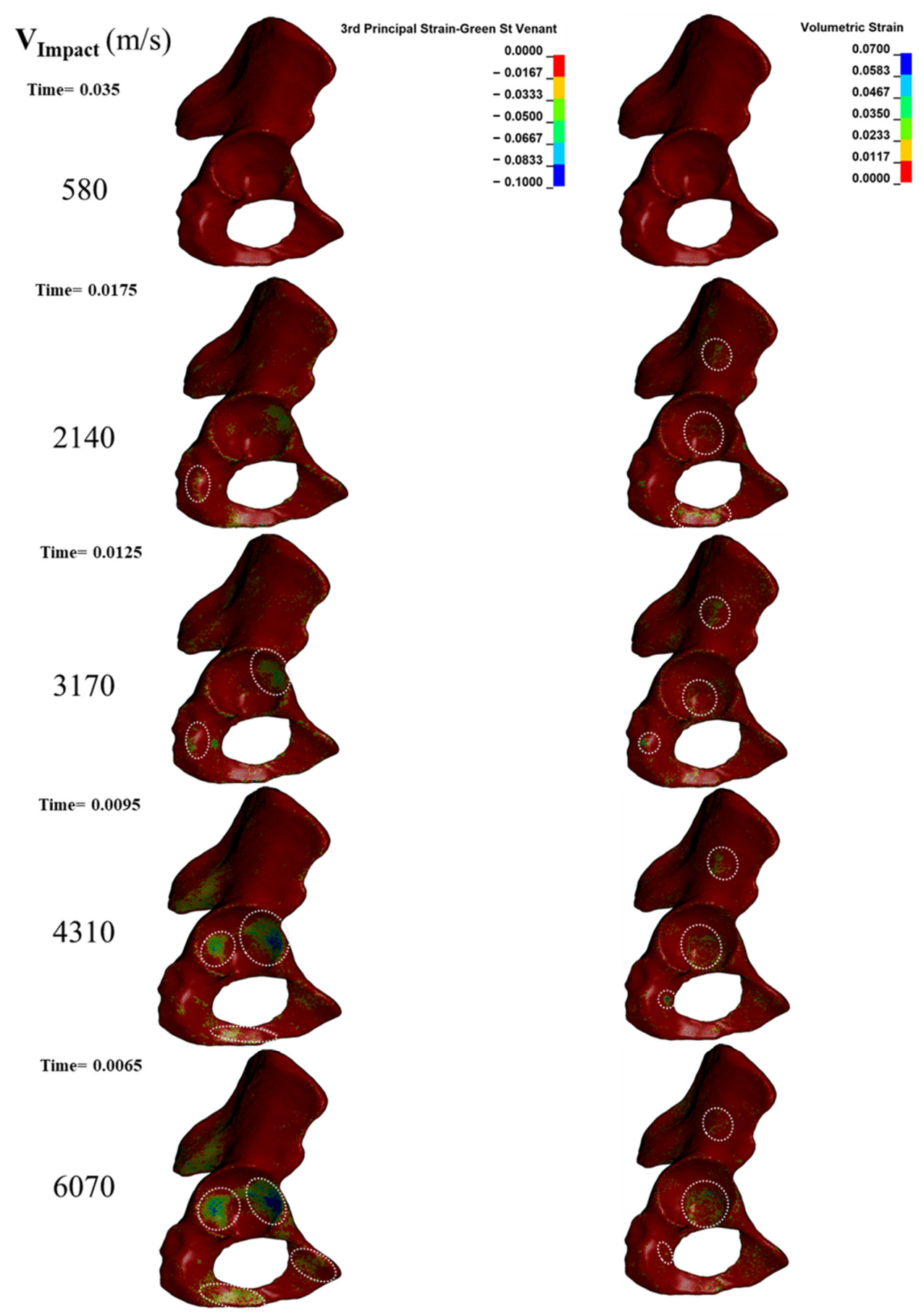

Figure 5. Effect of impact velocity on the compressive (left column) and tensile bone failure (right column) within the pelvis. 
Flooring material: for all the simulated flooring materials, a concentrated compressive bone failure at the anterior acetabular wall and a scattered compressive bone failure at the ischial tuberosity as well as the superior pubic ramus was observed. The tensile failure occurrence was in the minority in comparison with the compressive failure for all the flooring materials and only scattered tensile bone failures were observed mainly at the gluteus minimus attachment site and superior region of the cotyloid fossa. For the rigid ground, EVA foam, linoleum, plywood, and asphalt pavement, the tensile failure was also observed as a tiny region at the ischial tuberosity (Figure 6).

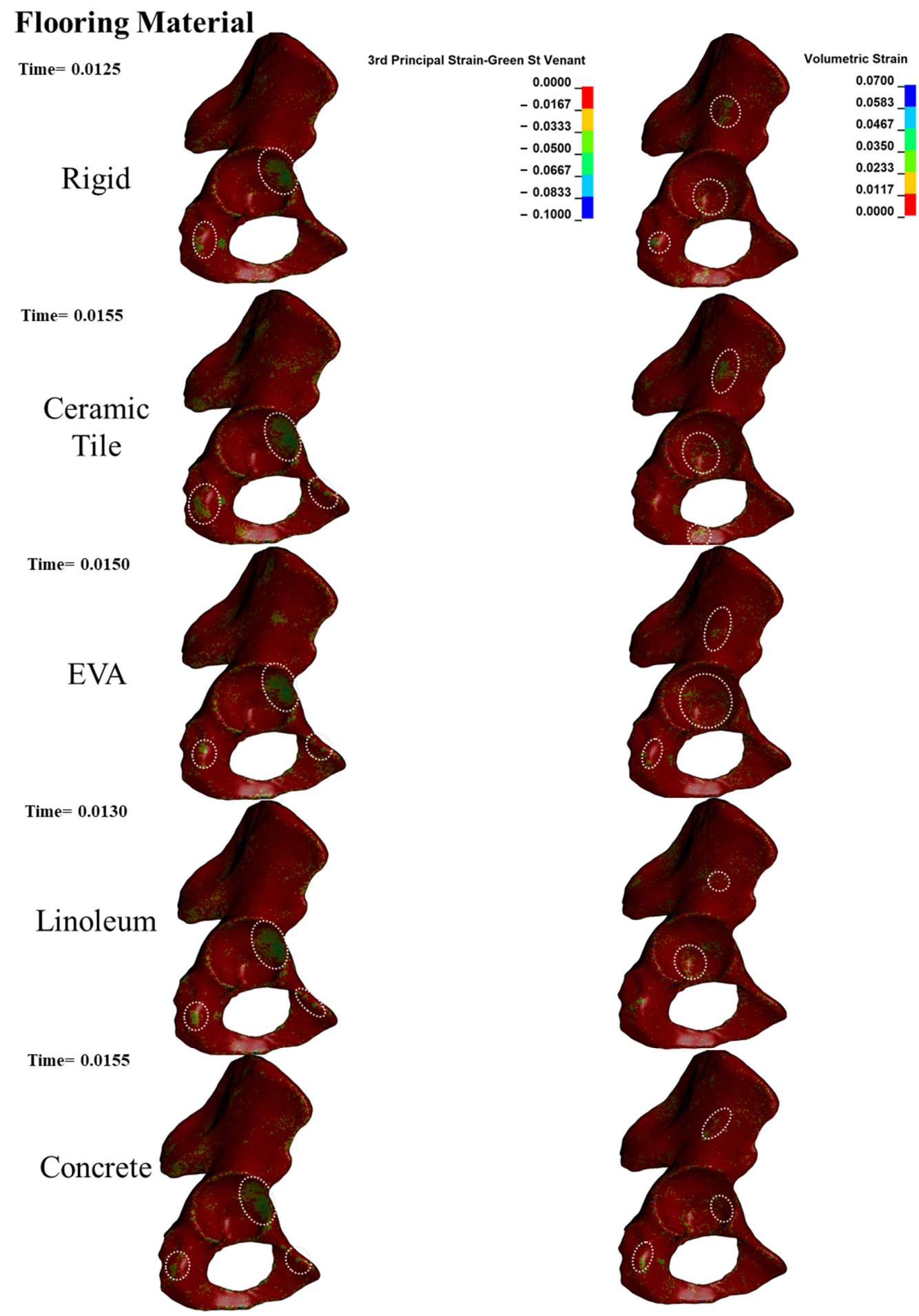

Figure 6. Cont. 


\section{Flooring Material}

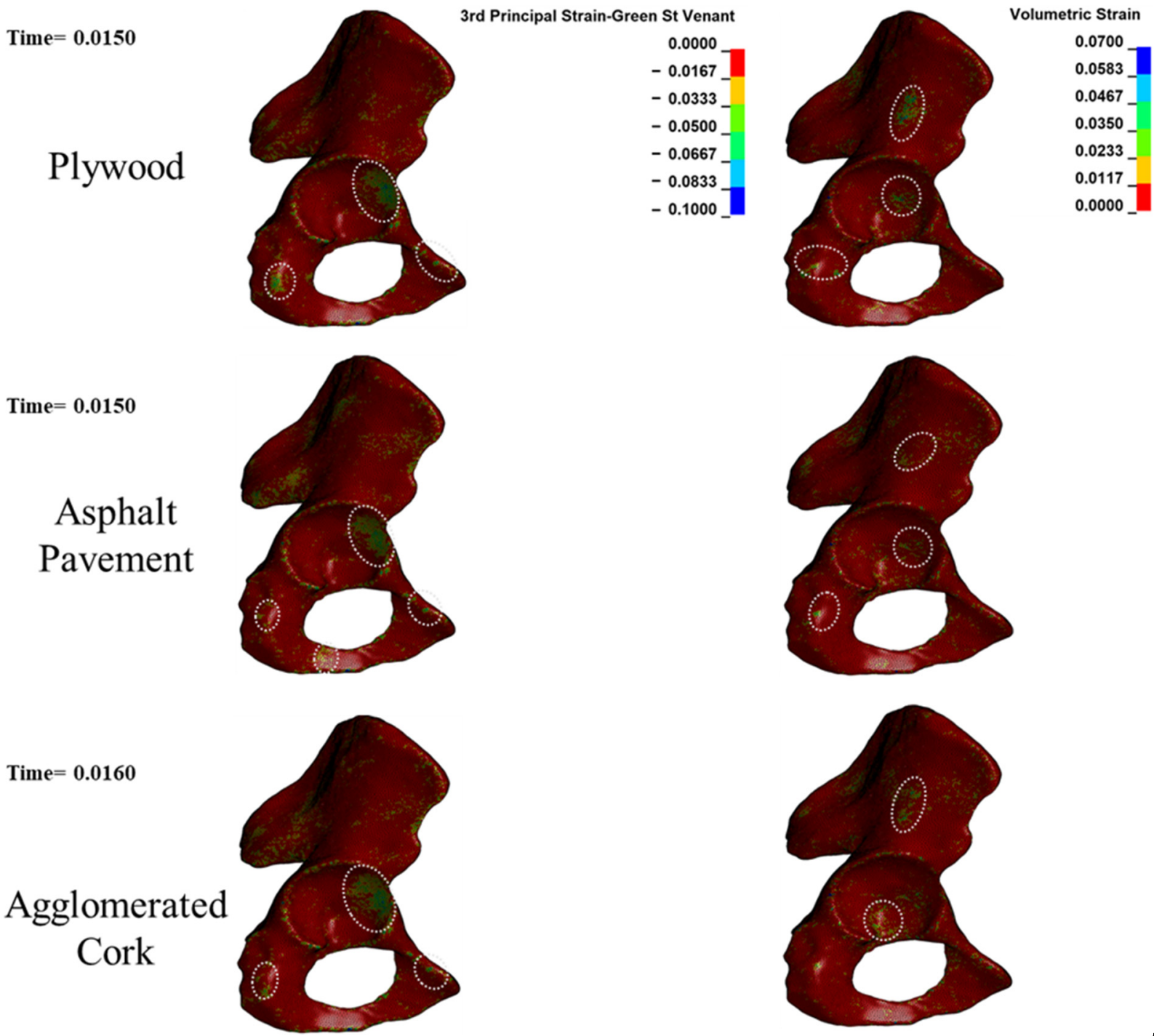

Figure 6. Effect of flooring material on the compressive (left column) and tensile bone failure (right column) within the pelvis.

TST stiffness: in general, changing the TST stiffness did not affect the type of acetabular fracture, as it was located at the posterior wall. By increasing the stiffness, the compressive bone failure area was split and concentrated at the anterior and posterior acetabular walls. Also, the tensile bone failure was negligible for all TST stiffnesses and compressive bone failure was the predominant mechanism of the acetabular bone failure (Figure 7). 
Time $=0.0095$

Base

$+6.5 \%$

Time $=0.0095$

$$
+13 \%
$$

$+19.5 \%$

Time $=0.0095$

Time $=\mathbf{0 . 0 0 9 5}$

$+26 \%$

Time $=0.0095$
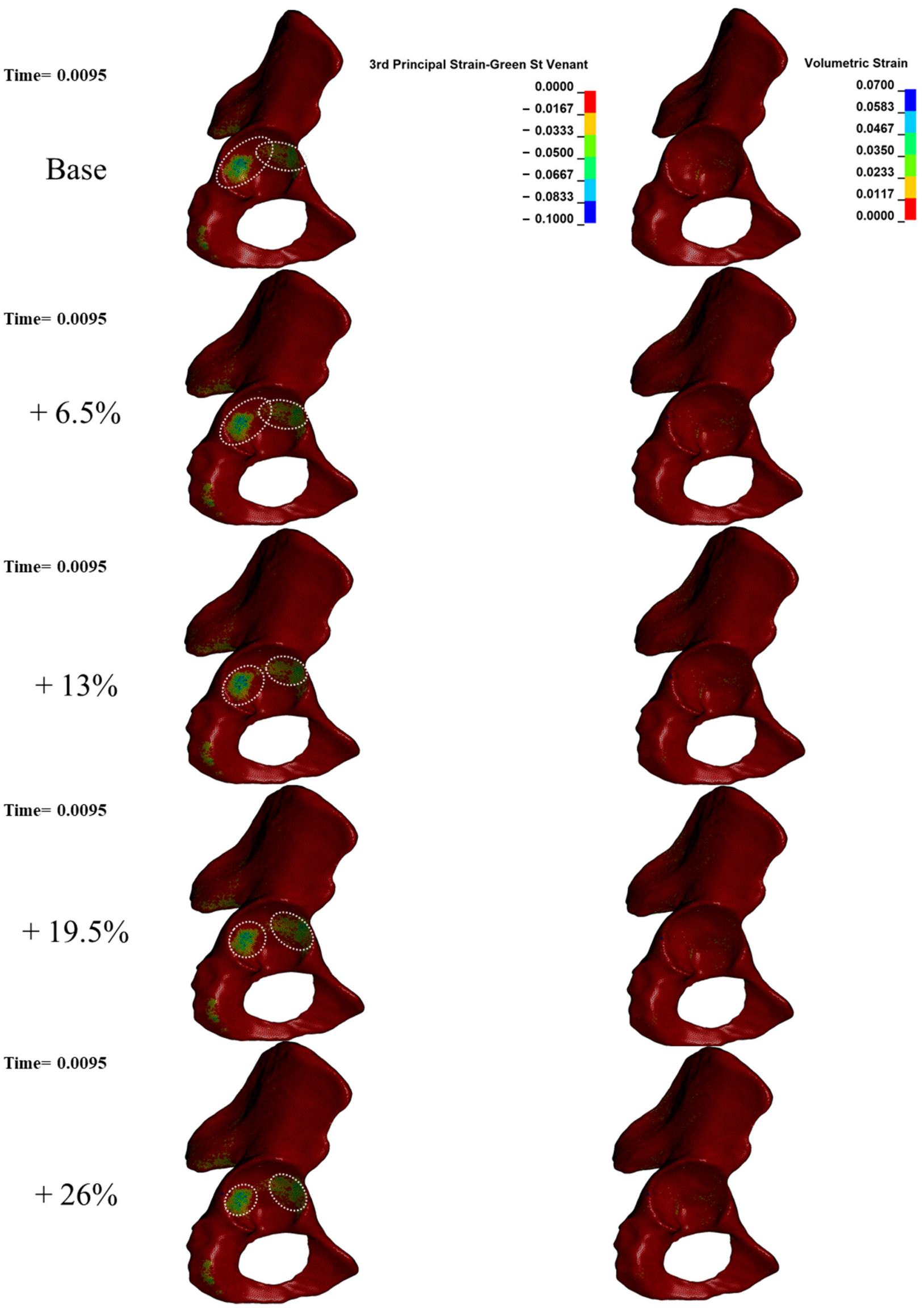

Figure 7. Effect of TST stiffness on the compressive (left column) and tensile bone failure (right column) within the pelvis. 


\section{Discussion}

This parametric simulation study assessed the effect of impact velocity, conventional flooring materials, and trochanteric soft-tissue stiffness on the incidence, severity, and type of acetabular fracture. While the effect of the body configuration on the acetabular fracture was studied previously [9], to the best of our knowledge, this is the first study evaluating the effect of $\mathrm{V}_{\text {Impact }}$, flooring material, and TST stiffness on acetabular bone failure.

Since this parametric study aimed to investigate the effect of $\mathrm{V}_{\text {Impact }}$, flooring material, and TST quality alterations on the relative incidence and type of acetabular fracture and no direct empirical validation was available, the model was validated against previous experimental studies. Previously, Askarinejad et al. [75] and Fleps et al. [13] used cadaveric testing to validate their finite element models of the femur, predicting the crack initiation and propagation. The GRF responses predicted by our models in terms of GRF ${ }_{\max }, \mathrm{t}_{\max }$, and shape of the curves were in good agreement with the previous studies with similar impact velocities $[27,45,72]$. Also, as discussed in the following paragraphs, the results obtained regarding the type of acetabular fracture and the effect of conventional flooring material were consistent with the clinical findings.

Previous studies $[10,30,32,76]$ have hypothesized that a greater height of the center of mass in taller persons results in a higher impact velocity, and consequently, an elevated risk of proximal femur fracture. Majumder et al. [32] showed that by increasing the $V_{\text {Impact }}$ from 1200 to $3170 \mathrm{~mm} / \mathrm{s}$, the strain ratio $\left(\varepsilon_{\max } / \varepsilon_{\text {ultimate }}\right)$ increases gradually and that by a further increase to $4790 \mathrm{~mm} / \mathrm{s}$, the strain ratio jumps up (more than two times in comparison with $3170 \mathrm{~mm} / \mathrm{s}$ ). The significant effect of $V_{\text {Impact }}$ was also demonstrated by our study for the acetabular fracture. In the current study, a substantial change in the pattern and intensity of compressive bone failure within the acetabulum was observed for $V_{\text {Impact }}>3170 \mathrm{~mm} / \mathrm{s}$ (Figure 2a). Also, Majumder et al. [32] stated that for $V_{\text {Impact }} \leq 1200 \mathrm{~mm} / \mathrm{s}$, the strain ratio would be less than one (0.77), which is consistent with our finding indicating no compressive bone failure for $V_{\text {Impact }}=580 \mathrm{~mm} / \mathrm{s}$ (Figure 5). Through another study on the lateral compressive failure of the pelvis, Bouquet and Ramet [77] introduced $8000 \mathrm{~N}$ as the threshold impact force for the incidence of obvious pelvic fracture, close to the corresponding $\mathrm{GRF}_{\max }$ $(8835 \mathrm{~N})$ of the $\mathrm{V}_{\text {Impact }}=3170 \mathrm{~mm} / \mathrm{s}$ in the present study (Figure 2a). Also, the $\mathrm{I}_{\mathrm{GRFmax}}$ for $\mathrm{V}_{\text {Impact }}>3170 \mathrm{~mm} / \mathrm{s}$ was more than two times that of $\mathrm{V}_{\text {Impact }} \leq 3170 \mathrm{~mm} / \mathrm{s}(43.63-62.24$ vs. 91.38-111.94 N.s) (Figure 2a). Not only was GRF affected greatly by the impact velocity, but the IRF was increased and $t_{\text {IRFmax }}$ decreased for all joints (including hip) by increasing $\mathrm{V}_{\text {Impact }}$. This can explain why a higher $\mathrm{V}_{\text {Impact }}$ can change the incidence and type of acetabular fracture. A higher $V_{\text {Impact }}$ is associated with a bigger impact force exerted in a shorter time (a higher strain rate), which makes the bone prone to fracture during falls [78]. In a recent study, Cecil et al. [79] concluded that by increasing the impact energy (velocity), the type of acetabular fracture changes. Also, they stated that the anterior wall fracture is common among elderly people who experience low-energy event trauma. A comparison of the regions with concentrated bone failure (Figure 5) with the fractured regions depicted in Judet and Letournel's acetabular fracture classification [80] (Appendix A, Figure A5) showed that the type of acetabular fracture is the anterior wall at low velocities $\left(V_{\text {Impact }} \leq 3170 \mathrm{~mm} / \mathrm{s}\right)$, whereas at higher velocities it changes to both associated columns, representing one of the most prevalent types of acetabular fracture in the senior population [4,81]. Overall, it seems that $\mathrm{V}_{\text {Impact }} \cong 3170 \mathrm{~mm} / \mathrm{s}$ can be considered as the threshold value for the incidence of acetabular bone failure. By assuming the body as a lumped falling object and the law of conservation of energy, the corresponding height to this impact velocity would be equal to $51.2 \mathrm{~cm}$. $\mathrm{V}_{\text {Impact }}=3170 \mathrm{~mm} / \mathrm{s}$ was reported by van den Kroonenberg [82] as the average value for hip impact velocity. This can explain why a sideways fall from a standing height among healthy young adults who have healthy bone remodeling rarely ends up in an acetabular fracture [83].

This study showed that, unlike impact velocity, conventional flooring materials did not affect the acetabular fracture remarkably. Only in the case of compliant surfaces such as agglomerated cork and linoleum GRF was slightly lower and $\mathrm{I}_{\mathrm{GRFmax}}$ was slightly higher than for the stiffer flooring (Figure 2b). Also, flooring material affected the $\mathrm{IRF}_{\max }$ within the 
joints, and the bone failure pattern negligibly. These findings are consistent with Lachance et al. [21], who concluded that while novel compliant flooring materials such as SmartCells and Sorbashock can attenuate the impact force considerably, conventional surfaces cannot notably reduce the exerting force to the hip during a fall. Similarly, Keenan et al. [84] concluded that conventional flooring can only provide negligible impact on the force attenuation, and novel flooring materials such as rubber with a honeycomb structure can attenuate the impact force up to 25\%. Also, Abdul Yamin et al. [26] stated that there is not an obvious difference in terms of trend, magnitude, and maximum GRF resulting from running on different flooring materials, and Simpson et al. [25] reported that $\mathrm{GRF}_{\max }$ ranges from 11.9 to $12.4 \mathrm{kN}$ for four different flooring materials. This is explained by the fact that the deceleration during impact is influenced by the initial conditions, viscoelastic properties of the ground, and the soft tissue. In terms of impact force attenuation, changing the conventional flooring material may not be as effective as previously thought with regard to the protection of elderly individuals from bone fractures in nursing facilities.

The dissipative role of trochanteric soft tissue can be attributed to its thickness or quality. Bouxsein et al. [31] and Majumder et al. [32] concluded that TST thinning increases the risk of proximal femur fracture, but they did not consider TST stiffness changes due to aging, as reported by Lim and Choi [50] and Choi et al. [34]. The current study revealed that TST stiffness mostly affects the post-impact phase. Also, it is strongly correlated with $\mathrm{GRF}_{\max }$ and $\mathrm{IRF}_{\max }$ within the sacroiliac joint, although this is not the case for $t_{\max }$, $\mathrm{I}_{\mathrm{GRFmax}}$, and $\mathrm{IRF}_{\max }$ within the hip or pubic symphysis joints. This shows that soft-tissue stiffening due to aging leads to a loss of the tissue's inherent ability to dissipate impact force; therefore, the tissue transfers a higher amount of force toward the sacroiliac joint. In combination with osteoporosis, this can explain to some extent why a low-energy sacroiliac fracture is more common among elderly people [85]. This study showed that changes in TST stiffness do not alter the type of acetabular fracture substantially and do not remarkably affect the bone failure within the acetabulum in comparison with TST thickness as reported by Majumder et al. [32]. This can be explained by the fact that while a thicker TST can absorb and distribute a bigger portion of the impact force when TST is compressed almost instantly $\left(\mathrm{t}_{\max } \approx 0.015 \mathrm{~s}\right)$, it behaves like a hard tissue [50], and the contribution of the viscous part of viscoelastic materials is, therefore, negligible [86]. Although aging affects the bone (as the recipient of impact load) and soft tissue (as the carrier of the impact load) simultaneously, the bone deterioration process through the loss of the bone minerals [31] and reduction in the trabecular number and connectivity [87] may play the main role in acetabular fracture.

Overall, it seems that among the studied variables, variation in the impact velocity has a more substantial effect on the occurrence and type of acetabular fracture than the change in TST stiffness or selecting a different conventional flooring material. Also, it appears that the acetabular bone strength is more critical in the prevention of acetabular fracture than the mechanical properties of load-transferring components such as conventional flooring material or TST stiffness.

This study also has some limitations. First, we did not consider muscle activation and recruitment pattern during sideways falls. Second, to simplify the model, only half of the soft tissue (the impact side) was modeled, and due to the abdominal CT images, only the pelvic girdle and the proximal section of the femur were reconstructed directly. Third, owing to the type of study (parametric) and the complexity of the modeling process, only a median model was developed. Fourth, the deformed TST was obtained by rotating the femur from supine to the sideways fall posture, which may not be exactly similar to a real case. Fifth, in this study, only the critical strain criterion was considered for bone failure, whereas using the coupled criterion method (strain and energy) may enhance bone failure prediction. Sixth, the viscous property of the cartilages was not considered for simplification. Finally, the study did not evaluate the effects of gender and osteoporosis, which will be the focus of future studies. 


\section{Conclusions}

In conclusion, this study demonstrated that impact velocity has a substantial impact on the incidence and type of acetabular fracture. The quality of bone, as the force recipient, and thickness of trochanteric soft tissue, as the force-transmitting component, appears to be more critical than flooring type and stiffness of trochanteric soft tissue in the incidence of an acetabular fracture. These results can be valuable in the prevention of low-energy acetabular fracture (resulted from sideways falls) or the design of falling techniques and protective devices such as hip pads. This study suggests that taller elderly persons with higher impact velocity are at a higher risk of acetabular fracture, and they should be monitored for osteoporosis. Also, decreasing the impact velocity by using martial techniques may protect elderly persons from acetabular fractures. In order to decrease the risk of acetabular fracture, nursing homes should select novel compliant floorings instead of conventional ones. Finally, although most hip pads are designed to protect elderly people from proximal fractures, their use will protect the acetabulum as well.

Author Contributions: S.K.: Conceptualization, investigation, formal analysis, methodology, validation, and visualization and writing the original draft and review and editing. P.T.: Formal analysis, methodology, validation, and review and editing. A.E.: Methodology, validation, and review \& editing. M.E.M.: Methodology, validation, and review and editing. S.S.: Supervision, conceptualization, methodology, validation, and review and editing. R.K.K.: Supervision, resources, funding acquisition, validation, review \& editing. T.J.: Supervision, administration, resources, funding acquisition, conceptualization, investigation, methodology, validation, and review \& editing. All authors have read and agreed to the published version of the manuscript.

Funding: This project was supported by the I4Future doctoral program under the Marie SkłodowskaCurie grant agreement No 713606, Academy of Finland (grant No 234529), and the Sigrid Juselius Foundation.

Institutional Review Board Statement: Not applicable.

Informed Consent Statement: Not applicable.

Data Availability Statement: The data presented in this study are available on request from the corresponding author. The data are not publicly available due to restrictions in the study permit.

Acknowledgments: CSC-IT Centre for Science LTD, Finland, is acknowledged for providing LSDYNA, Abaqus, and computational resources.

Conflicts of Interest: The authors declare no conflict of interest.

\section{Appendix A}

\section{Appendix A.1 Acetabular Cortical Thickness}

The location-dependent cortical thickness was obtained via slice-by-slice local thresholding (662-1988 HU). The thicknesses obtained were in the typical range [39,40]. The acetabular cortical bone thickness measurement is presented in four cross-sections. The measured thicknesses were consistent with Giudice et al. [40], who reported the ranges of $0-2.4 \mathrm{~mm}$ and $1.8-3.6 \mathrm{~mm}$ for the cortical thicknesses of the acetabular fossa and rim of the acetabulum, respectively. 

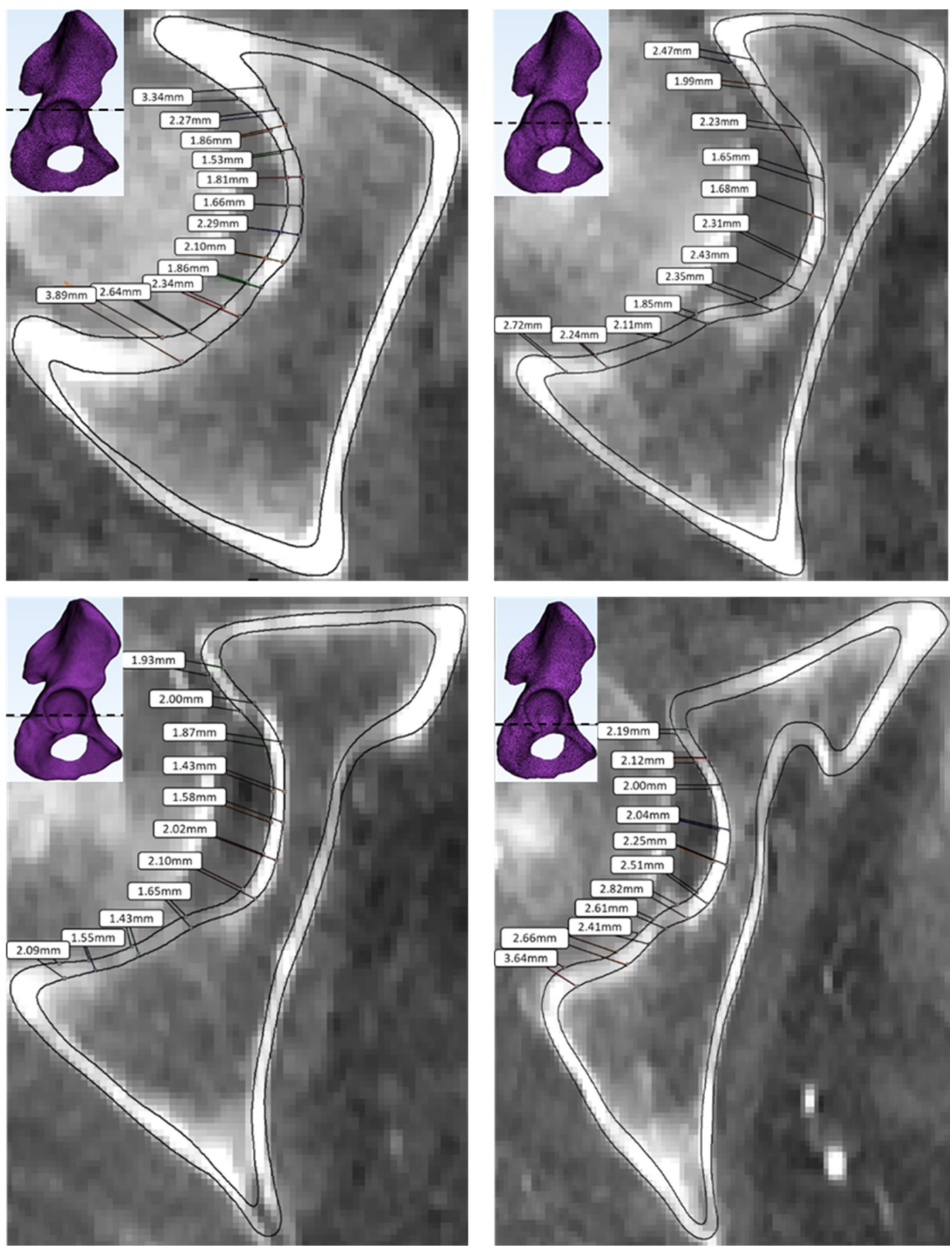

Figure A1. Cortical thickness at different sites of the acetabulum. 
Appendix A.2 Changing Body Configuration from Supine to Sideways Fall Posture
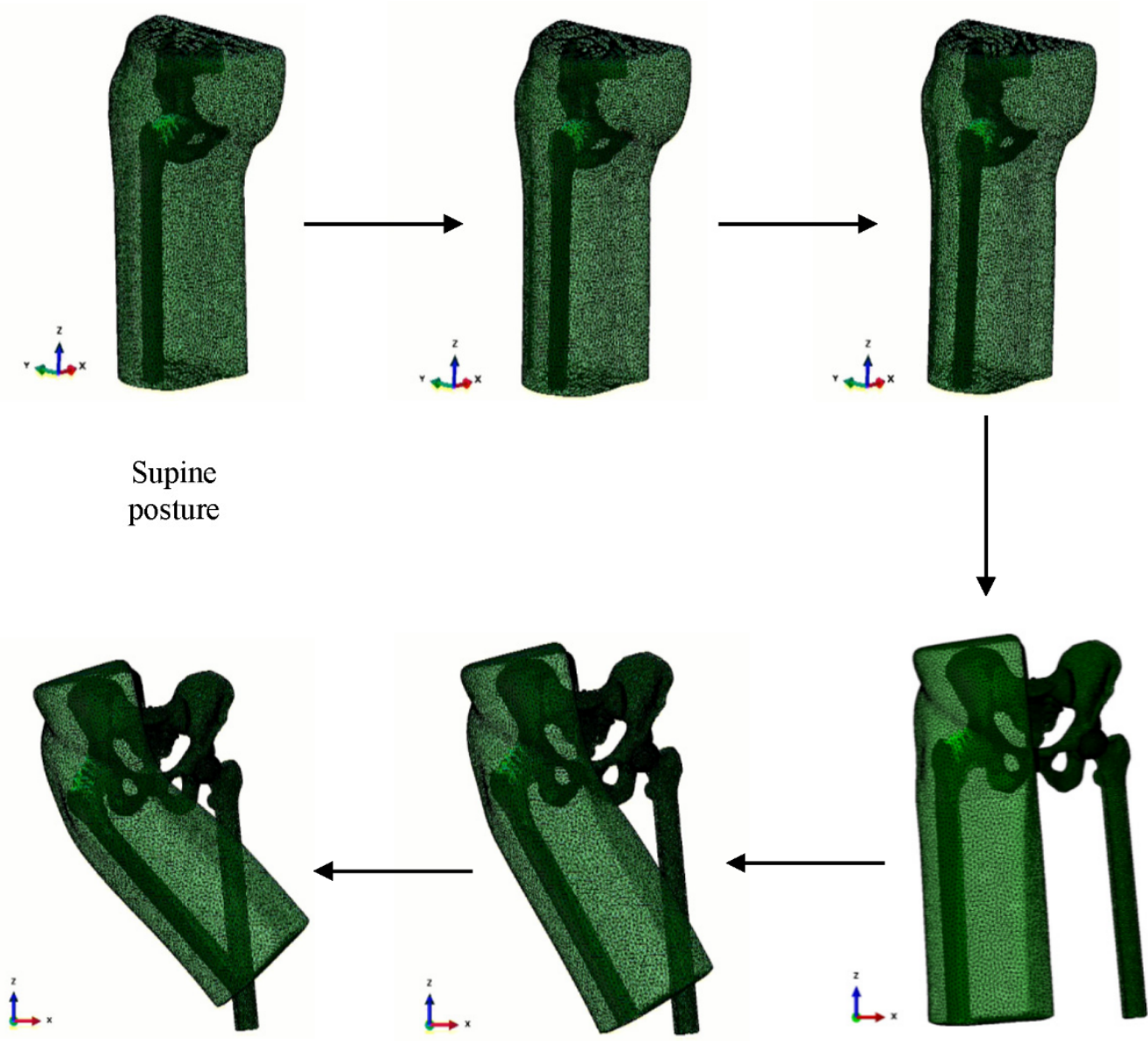

Sidewavs fall

(a)

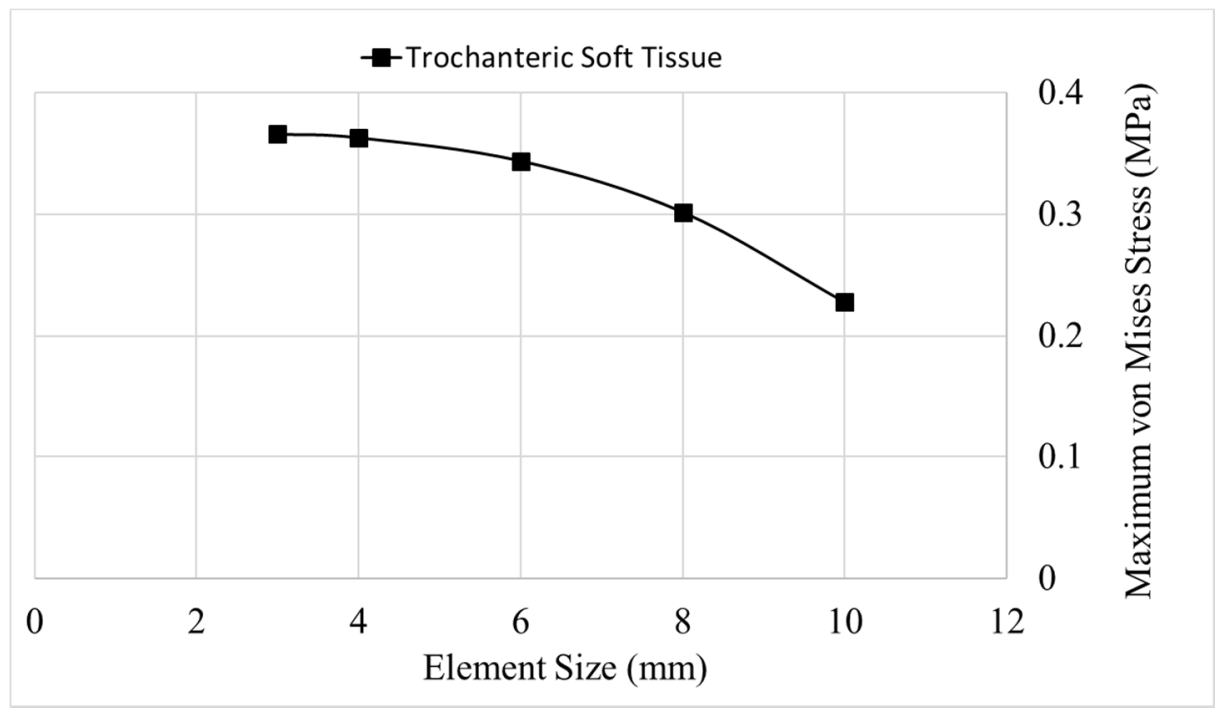

(b)

Figure A2. (a) Internal rotation and adduction from supine to sideways fall posture; (b) mesh convergence check. 
Appendix A.3 Illistration of the Whole Body and Initial Position of Models, and Results of the Mesh Convergence Study

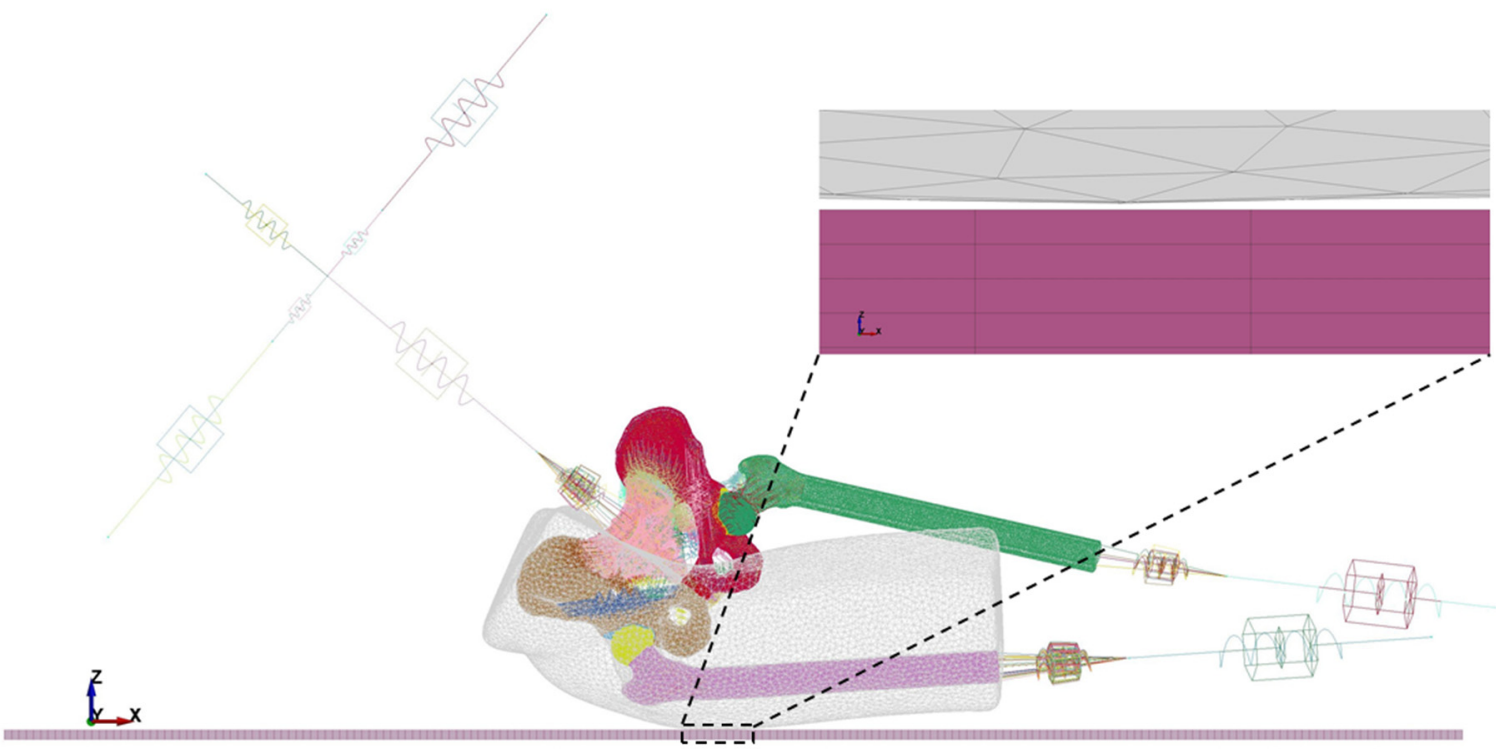

(a)
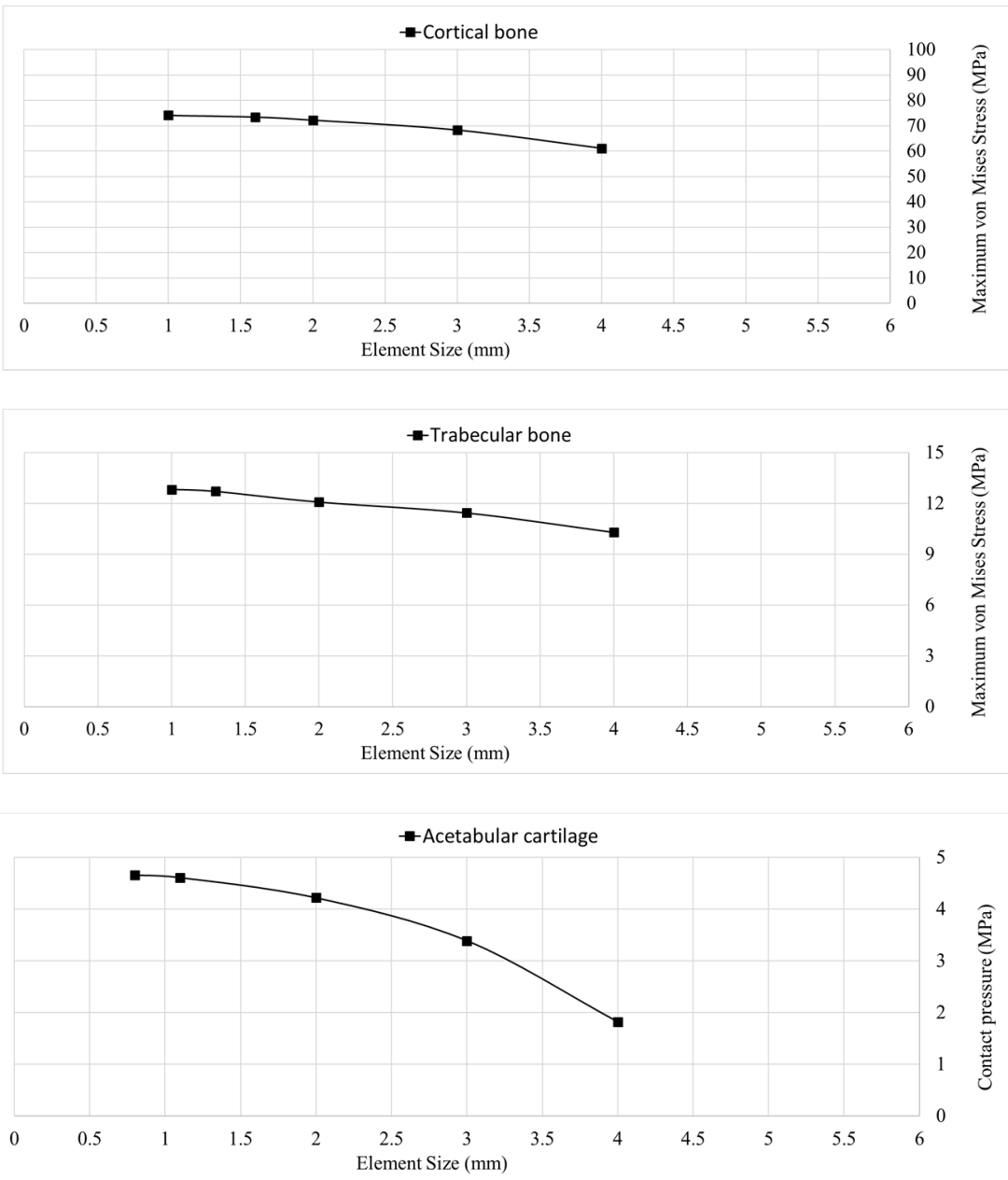

(b)

Figure A3. (a) Simple representation of the whole body; (b) mesh convergence check. 
Appendix A.4 Location of the Center of Lumped Masses and Mass, Stiffness, and Damping Factor of the Body Segments

\begin{tabular}{|c|c|c|c|c|}
\hline & Head & & \multirow{7}{*}{59.88} & \multirow{16}{*}{168.67} \\
\hline & 9.93 & & & \\
\hline & Neck & & & \\
\hline & 2.48 & & & \\
\hline \multicolumn{3}{|c|}{ Upper Trunk } & & \\
\hline Upper Arm & 37.54 & Upper Arm & & \\
\hline 9.385 & Middle Trunk & 9.385 & & \\
\hline Lower Arm & 21.5575 & Lower Arm & & \\
\hline 24.345 & Lower Trunk & 24.345 & & \\
\hline & 12.1725 & & & \\
\hline & Thigh & & & \\
\hline & 55.65 & & \multirow{5}{*}{108.79} & \\
\hline & Calf & & & \\
\hline & 46.23 & & & \\
\hline & Foot & & & \\
\hline & 6.91 & & & \\
\hline
\end{tabular}

Figure A4. Locations of the center of lumped masses (CoM).

Table A1. Mass of segments.

\begin{tabular}{|c|c|c|c|c|c|c|}
\hline \multicolumn{7}{|c|}{ Mass of Segments } \\
\hline Segment & B0 & B1 & B2 & $\begin{array}{l}\text { Calculated } \\
\text { Mass (Kg) }\end{array}$ & $\begin{array}{l}\text { Segmented-Part } \\
\text { Mass (Kg) }\end{array}$ & $\begin{array}{c}\text { Added } \\
\text { Lumped } \\
\text { Masses (Kg) }\end{array}$ \\
\hline Foot & -0.829 & 0.0077 & 0.0073 & 0.987491 & 0 & 0.987491 \\
\hline Calf & -1.592 & 0.03616 & 0.0121 & 3.197067 & 0 & 3.197067 \\
\hline * Thigh & -2.649 & 0.1463 & 0.0137 & 10.780579 & $0.38938327+10.3912$ & 0 \\
\hline Hand & -0.1165 & 0.0036 & 0.00175 & 0.4522725 & 0 & 0.4522725 \\
\hline Forearm & 0.3185 & 0.01445 & -0.00114 & 1.2244162 & 0 & 1.2244162 \\
\hline Upper arm & 0.25 & 0.03012 & -0.0027 & 2.083711 & 0 & 2.083711 \\
\hline Head and neck & 1.296 & 0.0171 & 0.0143 & 5.007581 & 0 & 5.007581 \\
\hline Upper part of the trunk & 8.2144 & 0.1862 & -0.0584 & 12.515272 & 0 & 12.515272 \\
\hline Middle part of the trunk & 7.181 & 0.2234 & -0.0663 & 12.976579 & 0 & 12.976579 \\
\hline * Lower part of the trunk & -7.498 & 0.0976 & 0.04896 & 8.1776832 & $0.234899+4.45969$ & 3.483091215 \\
\hline Total (Kg) & & & & 76.1281886 & 76.1387 & \\
\hline
\end{tabular}

* Trochanteric soft tissue segmented weight was distributed between the thigh and lower part of the trunk segments. 
Table A2. Stiffness and damping coefficients for spring [47] and damper [48].

\begin{tabular}{cccc}
\hline & \multicolumn{2}{c}{ Body Segments } \\
\hline From & To & Stiffness (N/mm) & Damping Coefficient (N s/mm) \\
\hline Head & Upper part of Trunk & 475.1 & 0.75 \\
\hline Upper part of Trunk & Middle part of the trunk & 584.2 & 1.6 \\
\hline Upper part of Trunk & Upper arm & 152.1 & 1.0 \\
\hline Upper arm & Forearm & 98.1 & 1.0 \\
\hline Middle part of the trunk & Lower part of the trunk & 555.1 & 1.8 \\
\hline Lower part of the trunk & Thigh & 130.5 & 1.1 \\
\hline Thigh & Calf & 68.9 & 1.0 \\
\hline Calf & Foot & 958.0 & 1.0 \\
\hline
\end{tabular}

Appendix A.5 Ligament Stiffness

Table A3. Ligaments' stiffnesses.

\begin{tabular}{|c|c|}
\hline Ligament & Stiffness $(\mathrm{N} / \mathrm{mm})$ \\
\hline Anterior sacroiliac & 2400 \\
\hline Posterior sacroiliac & 2400 \\
\hline Long posterior sacroiliac & 530 \\
\hline Sacrospinous & 800 \\
\hline Sacrotuberous & 1200 \\
\hline Anterior pubic & 800 \\
\hline Posterior pubic & 800 \\
\hline Superior pubic & 800 \\
\hline Inferior pubic & 800 \\
\hline Pubofemoral & 560 \\
\hline Iliofemoral & 99.3 \\
\hline Ischiofemoral & 36.9 \\
\hline Ligamentum teres & 16 \\
\hline Inguinal & 250 \\
\hline
\end{tabular}

Appendix A.6 Judet and Letournel Acetabular Fracture Classification

\section{Elementary Fractures}
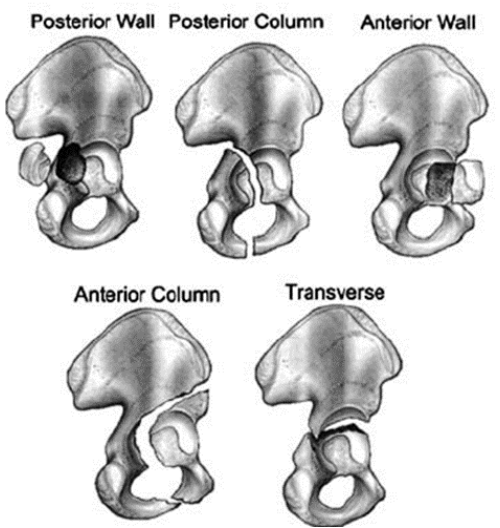

\section{Associated Fractures}

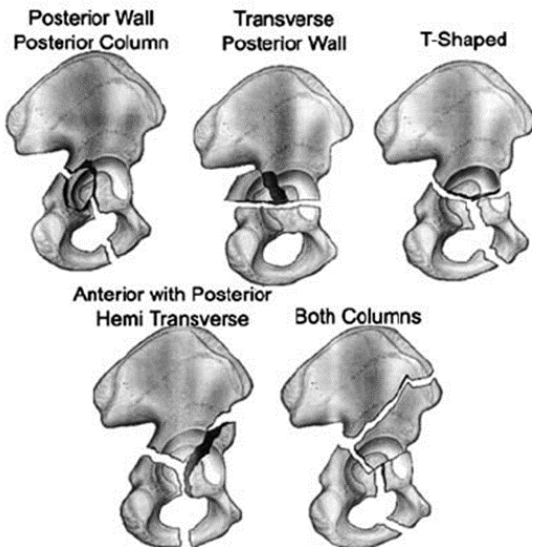

Figure A5. The Judet and Letournel acetabular fracture classification system [80]. Reprinted by permission from Springer Nature: Springer, HSS Journal, Acetabular Fractures in the Elderly: Treatment Recommendations, Eric Pagenkopf MD et al., (c) 2006 . 


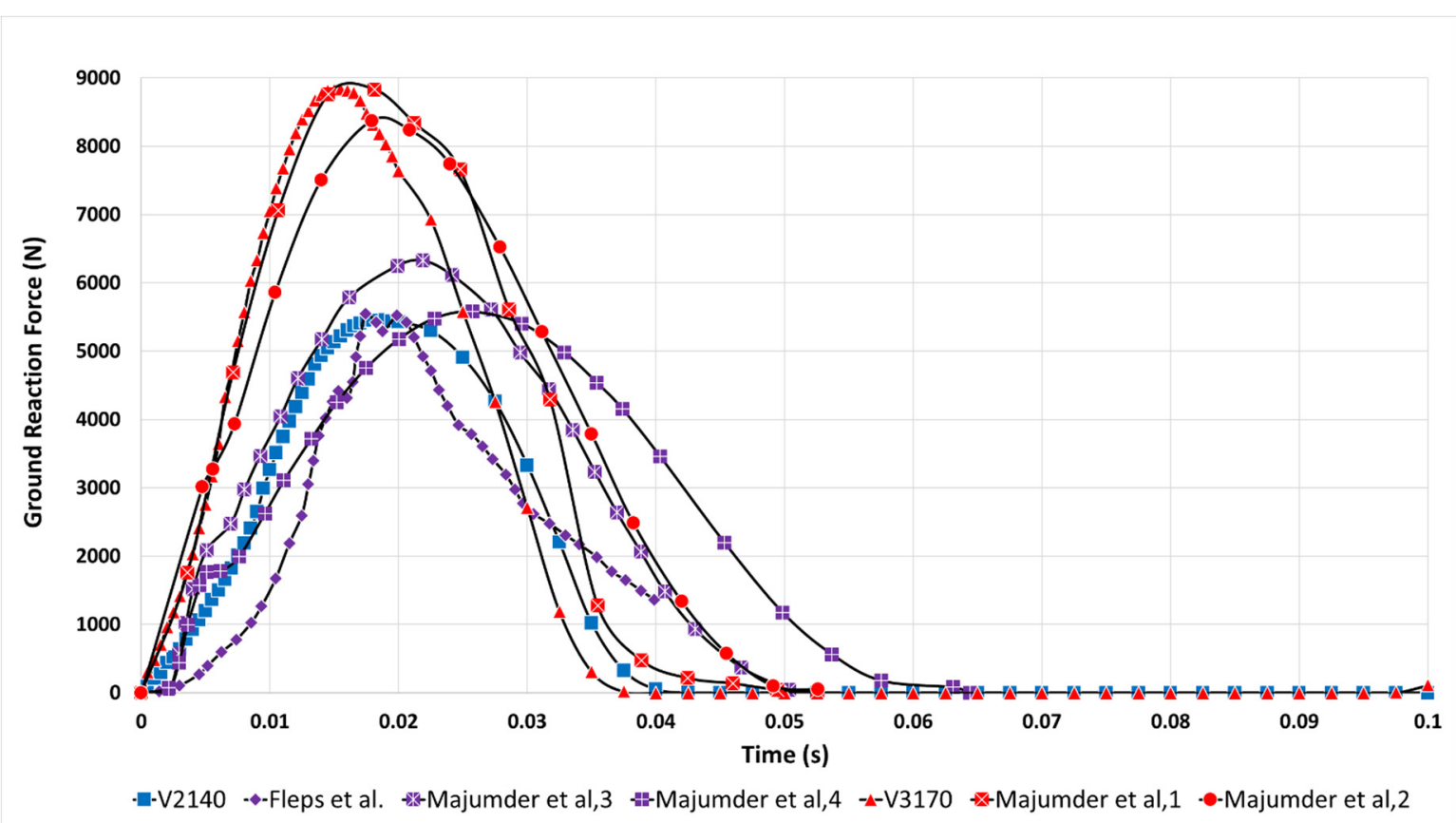

Figure A6. Ground reaction force (GRF): current study $\left(\mathrm{V}_{\text {impact }}=2140\right.$ and $\left.3170 \mathrm{~mm} / \mathrm{s}\right)$ vs. Fleps et al. [13] and Majumder et al. $[45,72]$ for sideways fall experiments.

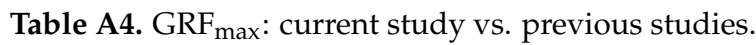

\begin{tabular}{ccc}
\hline Researchers & $\mathbf{V}_{\text {Impact }}(\mathbf{m m} / \mathbf{s})$ & GRF $_{\text {max }}(\mathbf{N})$ \\
\hline Current Study & 2140 & 5455 \\
Robinovitch et al. [88] & $1160-2580$ & $1700-5600$ \\
Robinovitch et al. [10] & $1400-6070$ & $5600-8600$ \\
Majumder et al. [32] & $1200-4790$ & $3419-11540$ \\
\hline Current Study & 3170 & 8835 \\
Robinovitch et al. [10] & $1400-6070$ & $5600-8600$ \\
Majumder et al. [32] & $1200-4790$ & $3419-11540$ \\
Kroonenberg et al. [89] & $3350-4340$ & $3720-9990$ \\
\hline
\end{tabular}

\section{Appendix B}

Table A5. Mechanical properties of tissues and ground.

\section{Cortical Bone (MAT_FU_CHANG_FOAM (083))}

\section{Density (tonne/ $\mathrm{mm}^{3}$ )}

Young's modulus (MPa)

\section{Rayleigh damping coefficient}

Table ID for nominal stress-strain data as a function of strain rate

\begin{tabular}{ccc}
\hline $1.800 \times 10^{-9}$ & $1.648 \times 10^{4}$ & 0.1 \\
\hline Strain rate evaluation flag & Tensile stress evaluation \\
\hline Principal strain rates for each principal direction & $\begin{array}{c}\text { input via load curves with the } \\
\text { tensile response corresponds } \\
\text { to negative values of stress } \\
\text { and strain }\end{array}$ \\
\hline
\end{tabular}


Table A5. Cont.

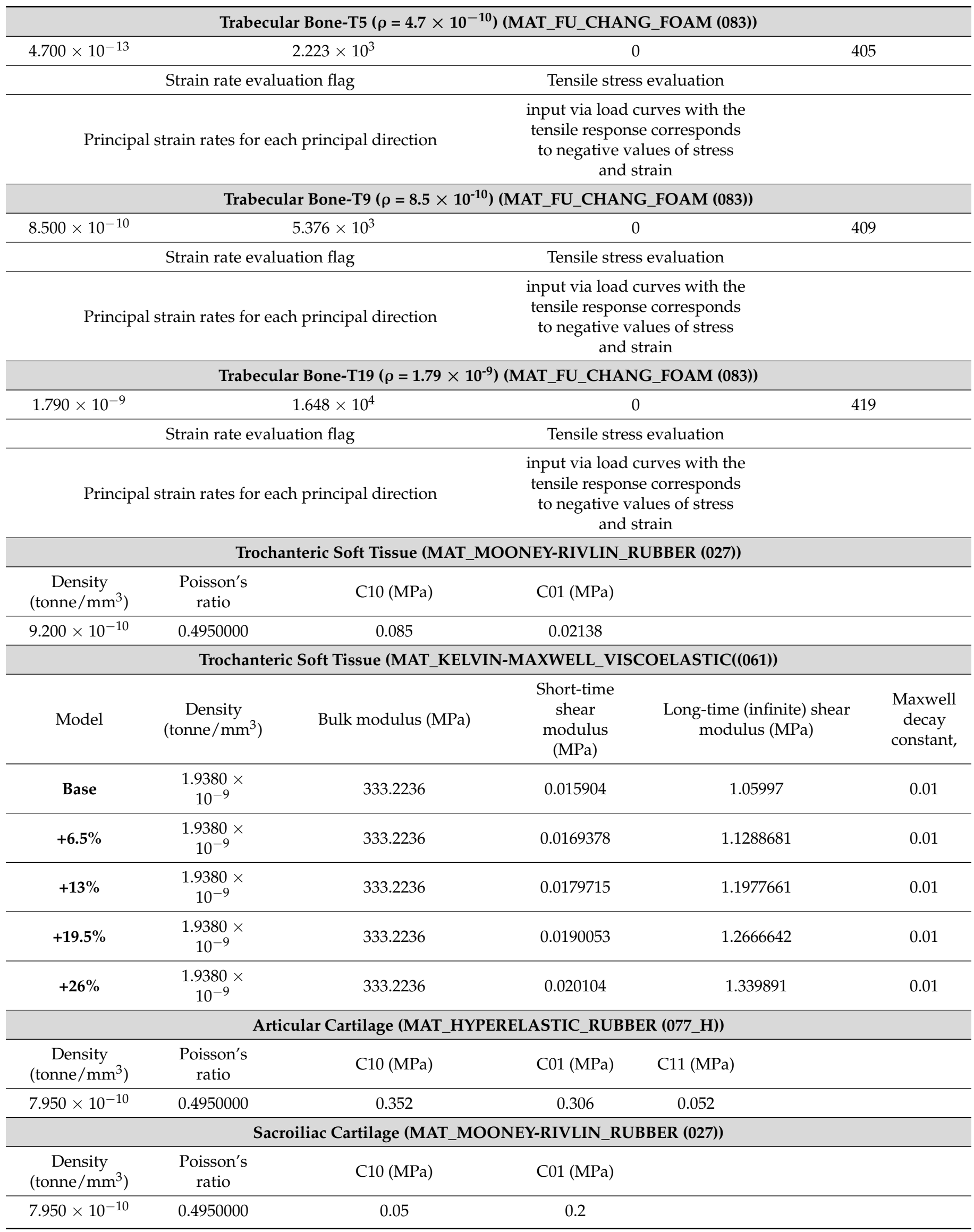


Table A5. Cont.

\section{Interpubic Disc (MAT_HYPERELASTIC_RUBBER (077_H))}

\begin{tabular}{|c|c|c|c|c|c|c|}
\hline $\begin{array}{c}\text { Density } \\
\text { (tonne } / \mathrm{mm}^{3} \text { ) }\end{array}$ & $\begin{array}{l}\text { Poisson's } \\
\text { ratio }\end{array}$ & $\begin{array}{l}\text { Number of Prony } \\
\text { series term }\end{array}$ & $\begin{array}{l}\text { Shear modulus for } \\
\text { frequency- } \\
\text { independent } \\
\text { damping }(\mathrm{MPa})\end{array}$ & $\mathrm{C} 10(\mathrm{MPa})$ & $\mathrm{C} 01(\mathrm{MPa})$ & $\mathrm{C} 11(\mathrm{MPa})$ \\
\hline $1.200 \times 10^{-9}$ & 0.4950000 & 2 & 0.5000000 & 0.05 & 0.2 & 0.25 \\
\hline $\begin{array}{l}\text { Shear relaxation } \\
\text { modulus }(\mathrm{MPa})\end{array}$ & $\begin{array}{l}\text { Decay } \\
\text { constant }\end{array}$ & \multicolumn{2}{|c|}{$\begin{array}{l}\text { Shear modulus for frequency-independent } \\
\text { damping (MPa) }\end{array}$} & \multicolumn{3}{|c|}{$\begin{array}{l}\text { Limit stress for frequency independent, } \\
\text { frictional, damping }\end{array}$} \\
\hline 0.016 & 0.54 & \multicolumn{2}{|c|}{0.07} & \multicolumn{3}{|c|}{0.06} \\
\hline \multicolumn{7}{|c|}{ Ceramic Tile (MAT_JOHNSON_HOLMQUIST_CERAMICS (110)) } \\
\hline $\begin{array}{c}\text { Density } \\
\text { (tonne } / \mathrm{mm}^{3} \text { ) }\end{array}$ & $\begin{array}{l}\text { Shear } \\
\text { Modulus } \\
(\mathrm{MPa})\end{array}$ & $\begin{array}{l}\text { Intact normalized } \\
\text { strength parameter }\end{array}$ & $\begin{array}{c}\text { Fractured } \\
\text { normalized } \\
\text { strength parameter }\end{array}$ & $\begin{array}{l}\text { Fractured } \\
\text { strength } \\
\text { parameter }\end{array}$ & $\begin{array}{c}\text { Intact } \\
\text { strength } \\
\text { parameter }\end{array}$ & $\begin{array}{l}\text { Reference } \\
\text { strain rate } \\
(1 / s)\end{array}$ \\
\hline $3.921 \times 10^{-9}$ & $9.016 \times 10^{-4}$ & 0.9300000 & 0.3100000 & 0.6000000 & 0.6000000 & 1 \\
\hline $\begin{array}{l}\text { Maximum } \\
\text { tensile strength } \\
(\mathrm{MPa})\end{array}$ & $\begin{array}{l}\text { Pressure } \\
\text { component at } \\
\text { the Hugoniot } \\
\text { elastic limit. }\end{array}$ & \multicolumn{2}{|c|}{$\begin{array}{c}\text { Fraction of elastic energy loss converted to } \\
\text { hydrostatic energy }\end{array}$} & \multicolumn{3}{|c|}{ Parameter for plastic strain to fracture } \\
\hline 200.00000 & $1.460 \times 10^{3}$ & \multicolumn{2}{|c|}{1} & \multicolumn{3}{|c|}{0.0050000} \\
\hline \multicolumn{2}{|c|}{$\begin{array}{l}\text { Parameter for the plastic strain to } \\
\text { fracture (exponent) }\end{array}$} & \multicolumn{5}{|c|}{ First pressure coefficient (equivalent to the bulk modulus) (MPa) } \\
\hline \multicolumn{2}{|c|}{1.000} & \multicolumn{5}{|c|}{$1.310 \times 10^{5}$} \\
\hline \multicolumn{7}{|c|}{ Ethylene-vinyl acetate (MAT_OGDEN_RUBBER (077)) } \\
\hline $\begin{array}{c}\text { Density } \\
\text { (tonne } / \mathrm{mm}^{3} \text { ) }\end{array}$ & $\begin{array}{l}\text { Shear } \\
\text { Modulus } \\
(\mathrm{MPa})\end{array}$ & Poisson's ratio & $\mu_{1}(\mathrm{MPa})$ & $\mu_{2}(\mathrm{MPa})$ & $\alpha_{1}$ & $\alpha_{2}$ \\
\hline $2.000 \times 10^{-9}$ & 10.000 & 0.4800 & 7.000000 & 2.600000 & 0.800000 & 2.600000 \\
\hline \multicolumn{7}{|c|}{ Plywood (MAT_WOOD_PINE (143)) } \\
\hline $\begin{array}{c}\text { Density } \\
\text { (tonne } / \mathrm{mm}^{3} \text { ) }\end{array}$ & $\begin{array}{l}\text { Rate effects } \\
\text { option }\end{array}$ & $\begin{array}{l}\text { Erosion } \\
\text { perpendicular to the } \\
\text { grain }\end{array}$ & $\begin{array}{l}\text { Parallel normal } \\
\text { modulus (MPa) }\end{array}$ & $\begin{array}{l}\text { Perpendicular } \\
\text { normal } \\
\text { modulus } \\
(\mathrm{MPa})\end{array}$ & $\begin{array}{l}\text { Parallel shear } \\
\text { modulus } \\
(\mathrm{MPa})\end{array}$ & $\begin{array}{l}\text { Perpendicular } \\
\text { shear } \\
\text { modulus } \\
(\mathrm{MPa})\end{array}$ \\
\hline $6.731 \times 10^{-10}$ & Included & Included & $1.549 \times 10^{4}$ & 910.1 & 789.8 & 3.233E2 \\
\hline $\begin{array}{l}\text { Parallel major } \\
\text { Poisson's ratio }\end{array}$ & $\begin{array}{l}\text { Parallel } \\
\text { tensile } \\
\text { strength } \\
(\mathrm{MPa}) \\
\end{array}$ & $\begin{array}{l}\text { Parallel compressive } \\
\text { strength }(\mathrm{MPa})\end{array}$ & $\begin{array}{l}\text { Perpendicular } \\
\text { tensile strength } \\
(\mathrm{MPa})\end{array}$ & $\begin{array}{l}\text { Perpendicular } \\
\text { compressive } \\
\text { strength } \\
(\mathrm{MPa}) \\
\end{array}$ & $\begin{array}{l}\text { Parallel shear } \\
\text { strength } \\
(\mathrm{MPa})\end{array}$ & $\begin{array}{l}\text { Perpendicular } \\
\text { SHEAR } \\
\text { strength } \\
(\mathrm{MPa}) \\
\end{array}$ \\
\hline 0.2586000 & 66.190 & 37.000 & 2.139 & 7.145 & 8.526 & 11.940 \\
\hline $\begin{array}{l}\text { Parallel fracture } \\
\text { energy in tension } \\
(\mathrm{N} \cdot \mathrm{mm})\end{array}$ & $\begin{array}{l}\text { Parallel } \\
\text { fracture } \\
\text { energy in } \\
\text { shear } \\
(\mathrm{N} \cdot \mathrm{mm})\end{array}$ & $\begin{array}{l}\text { Parallel softening } \\
\text { parameter }\end{array}$ & $\begin{array}{l}\text { Parallel maximum } \\
\text { damage }\end{array}$ & $\begin{array}{l}\text { Perpendicular } \\
\text { fracture } \\
\text { energy in } \\
\text { tension } \\
(\mathrm{N} \cdot \mathrm{mm})\end{array}$ & $\begin{array}{l}\text { Perpendicular } \\
\text { fracture } \\
\text { energy in } \\
\text { shear } \\
(\mathrm{N} \cdot \mathrm{mm})\end{array}$ & $\begin{array}{l}\text { Perpendicular } \\
\text { softening } \\
\text { parameter }\end{array}$ \\
\hline 13.840 & 50.160 & 30.000 & 0.9999 & 0.277 & 1.003 & 30.000 \\
\hline $\begin{array}{l}\text { Perpendicular } \\
\text { maximum } \\
\text { damage }\end{array}$ & $\begin{array}{c}\text { Parallel } \\
\text { hardening } \\
\text { initiation }\end{array}$ & $\begin{array}{l}\text { Parallel hardening } \\
\quad \text { rate }\left(\mathrm{s}^{-1}\right)\end{array}$ & $\begin{array}{l}\text { Perpendicular } \\
\text { hardening } \\
\text { initiation }\end{array}$ & $\begin{array}{l}\text { Perpendicular } \\
\text { hardening } \\
\text { rate }\left(\mathrm{s}^{-1}\right)\end{array}$ & Material a & xes option \\
\hline 0.9999 & 0.500 & 1.000 & 0.400 & 0.252 & $\begin{array}{r}\text { Globally ort } \\
\text { material axes } \\
\text { vectors de }\end{array}$ & $\begin{array}{l}\text { lotropic with } \\
\text { determined by } \\
\text { ined below }\end{array}$ \\
\hline
\end{tabular}


Table A5. Cont.

\begin{tabular}{|c|c|c|c|c|c|c|c|}
\hline \multicolumn{8}{|c|}{ Plywood (MAT_WOOD_PINE (143)) } \\
\hline $\begin{array}{l}\text { Components of } \\
\text { vector (A1) }\end{array}$ & $\begin{array}{l}\text { Components } \\
\text { of vector }(\mathrm{A} 2)\end{array}$ & \multicolumn{2}{|c|}{$\begin{array}{l}\text { Components of vector } \\
\text { (A3) }\end{array}$} & $\begin{array}{l}\text { Components of } \\
\text { vector (D1) }\end{array}$ & $\begin{array}{c}\text { Components } \\
\text { of vector } \\
\text { (D2) }\end{array}$ & \multicolumn{2}{|c|}{$\begin{array}{l}\text { Components of vector } \\
\text { (D3) }\end{array}$} \\
\hline 0.0 & 1.0 & \multicolumn{2}{|c|}{0.0} & 1.0 & 0.0 & \multicolumn{2}{|c|}{0.0} \\
\hline \multicolumn{8}{|c|}{ Agglomerated cork (MAT_LOW_DENSITY_FOAM) } \\
\hline $\begin{array}{c}\text { Density } \\
\text { (tonne } / \mathrm{mm}^{3} \text { ) }\end{array}$ & $\begin{array}{l}\text { Young's } \\
\text { modulus } \\
(\mathrm{MPa})\end{array}$ & \multicolumn{2}{|c|}{$\begin{array}{l}\text { Tension cut-off stress } \\
\qquad(\mathrm{MPa})\end{array}$} & $\begin{array}{l}\text { Hysteretic } \\
\text { unloading factor }\end{array}$ & $\begin{array}{l}\text { Decay } \\
\text { constant to } \\
\text { model } \\
\text { creep in } \\
\text { unloading }\end{array}$ & $\begin{array}{l}\text { Viscous } \\
\text { coefficient }\end{array}$ & $\begin{array}{l}\text { Shape } \\
\text { factor for } \\
\text { unload- } \\
\text { ing }\end{array}$ \\
\hline $2.000 \times 10^{-10}$ & 6.000 & \multicolumn{2}{|c|}{9000.000} & 1 & 0 & 0.500 & 9.000 \\
\hline $\begin{array}{l}\text { Optional decay } \\
\text { constant }\end{array}$ & \multicolumn{3}{|c|}{$\begin{array}{l}\text { Stiffness coefficient for contact interface } \\
\text { stiffness }\end{array}$} & \multicolumn{2}{|c|}{$\begin{array}{c}\text { Load curve ID for nominal stress } \\
\text { versus strain }\end{array}$} & & \\
\hline 0.010 & \multicolumn{3}{|c|}{90.000} & \multicolumn{2}{|l|}{422} & & \\
\hline \multicolumn{8}{|c|}{ Concrete (MAT_CSCM_CONCRETE (159)) } \\
\hline $\begin{array}{c}\text { Density } \\
\text { (tonne } / \mathrm{mm}^{3} \text { ) }\end{array}$ & \multicolumn{3}{|c|}{ Elements erode when damage exceeds 0.99} & \multicolumn{2}{|c|}{$\begin{array}{l}\text { Unconfined compression strength } \\
\qquad(\mathrm{MPa})\end{array}$} & \multicolumn{2}{|c|}{$\begin{array}{c}\text { Maximum aggregate size, } \\
\text { Dagg }(\mathrm{mm})\end{array}$} \\
\hline $2.320 \times 10^{-9}$ & \multicolumn{3}{|c|}{1.050} & \multicolumn{2}{|c|}{30.000} & \multicolumn{2}{|c|}{19} \\
\hline \multicolumn{8}{|c|}{ Asphalt Pavement- AC20 (MAT_PIECEWISE_LINEAR_PLASTICITY (024)) } \\
\hline $\begin{array}{c}\text { Density } \\
\text { (tonne } / \mathrm{mm}^{3} \text { ) }\end{array}$ & $\begin{array}{l}\text { Young's } \\
\text { modulus } \\
(\mathrm{MPa})\end{array}$ & $\begin{array}{l}\text { Poisson's } \\
\text { ratio }\end{array}$ & $\begin{array}{l}\text { Yield stress } \\
\qquad(\mathrm{MPa})\end{array}$ & $\begin{array}{l}\text { Tangent modulus } \\
\qquad(\mathrm{MPa})\end{array}$ & $\begin{array}{l}\text { Plastic } \\
\text { strain to } \\
\text { failure }\end{array}$ & $\begin{array}{l}\text { Strain rate } \\
\text { coefficient } C \\
\left(\mathrm{~s}^{-1}\right)\end{array}$ & $\begin{array}{l}\text { Strain } \\
\text { rate coef- } \\
\text { ficient } \\
\text { P }\end{array}$ \\
\hline $2.400 \times 10^{-9}$ & 2200.000 & 0.350 & 200.000 & 815.000 & 0.709 & 40 & 5 \\
\hline \multicolumn{8}{|c|}{ Asphalt Pavement- Concrete Base (MAT_PIECEWISE_LINEAR_PLASTICITY (024)) } \\
\hline $\begin{array}{c}\text { Density } \\
\text { (tonne } / \mathrm{mm}^{3} \text { ) }\end{array}$ & $\begin{array}{l}\text { Young's } \\
\text { modulus } \\
(\mathrm{MPa})\end{array}$ & $\begin{array}{l}\text { Poisson's } \\
\quad \text { ratio }\end{array}$ & $\begin{array}{l}\text { Yield stress } \\
\qquad(\mathrm{MPa})\end{array}$ & $\begin{array}{l}\text { Tangent modulus } \\
\qquad(\mathrm{MPa})\end{array}$ & $\begin{array}{l}\text { Plastic } \\
\text { strain to } \\
\text { failure }\end{array}$ & $\begin{array}{c}\text { Strain rate } \\
\text { coefficient } C \\
\left(\mathrm{~s}^{-1}\right)\end{array}$ & $\begin{array}{l}\text { Strain } \\
\text { rate coef- } \\
\text { ficient } \\
\text { P }\end{array}$ \\
\hline $2.200 \times 10^{-9}$ & 1500.000 & 0.250 & 180.000 & 600.000 & 0.680 & 40 & 5 \\
\hline \multicolumn{8}{|c|}{ Asphalt Pavement- Soil Base (MAT_PIECEWISE_LINEAR_PLASTICITY (024)) } \\
\hline $\begin{array}{c}\text { Density } \\
\text { (tonne } / \mathrm{mm}^{3} \text { ) }\end{array}$ & $\begin{array}{l}\text { Young's } \\
\text { modulus } \\
(\mathrm{MPa})\end{array}$ & $\begin{array}{l}\text { Poisson's } \\
\quad \text { ratio }\end{array}$ & $\begin{array}{l}\text { Yield stress } \\
\qquad(\mathrm{MPa})\end{array}$ & $\begin{array}{l}\text { Tangent modulus } \\
\qquad(\mathrm{MPa})\end{array}$ & $\begin{array}{l}\text { Plastic } \\
\text { strain to } \\
\text { failure }\end{array}$ & $\begin{array}{l}\text { Strain rate } \\
\text { coefficient } C \\
\left(\mathrm{~s}^{-1}\right)\end{array}$ & $\begin{array}{l}\text { Strain } \\
\text { rate coef- } \\
\text { ficient } \\
\text { P }\end{array}$ \\
\hline $1.800 \times 10^{-9}$ & $4.500 \times 10^{3}$ & 0.400 & 50.000 & 160.000 & 0.789 & 40 & 5 \\
\hline
\end{tabular}




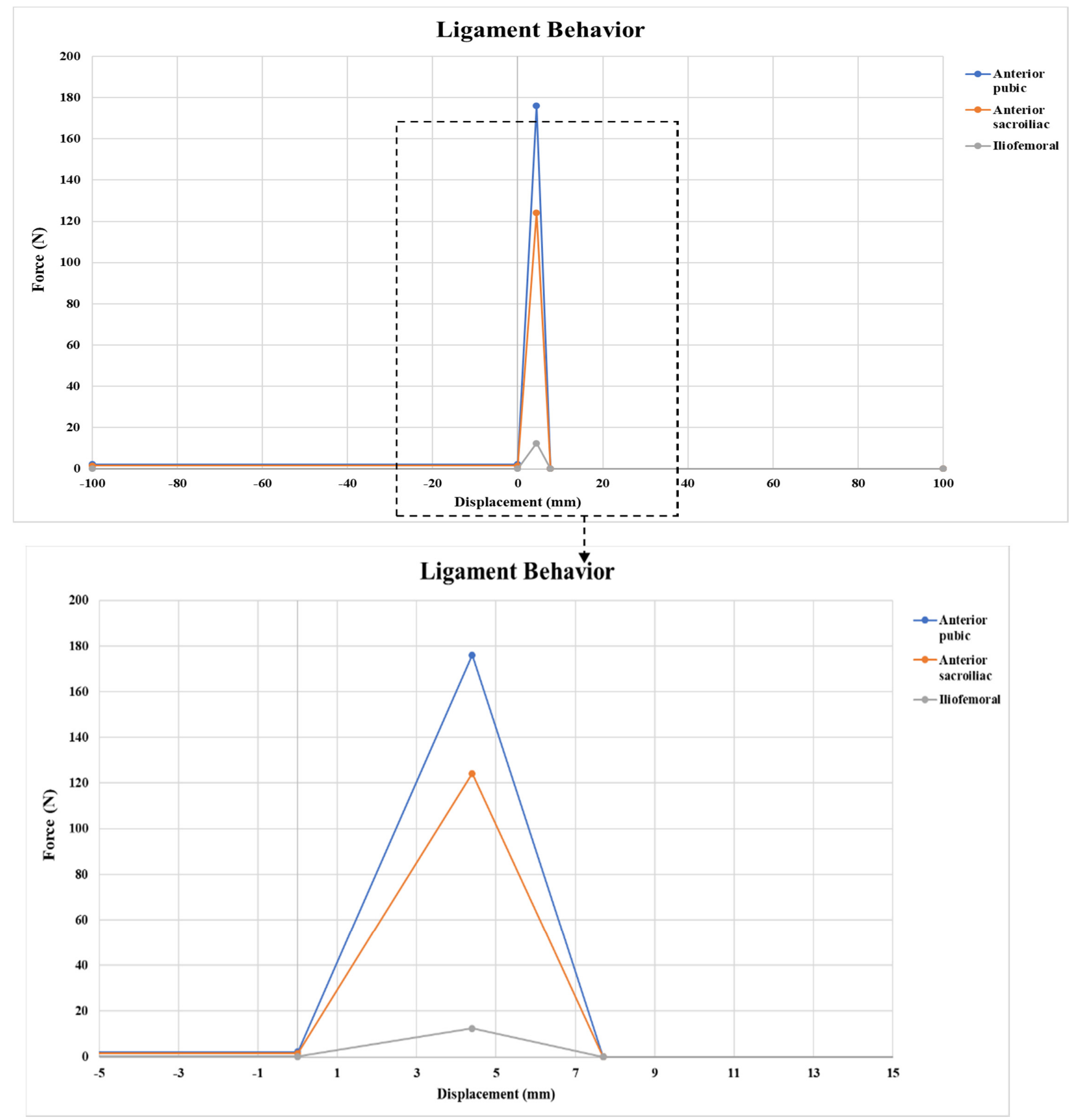

Figure A7. Cont. 


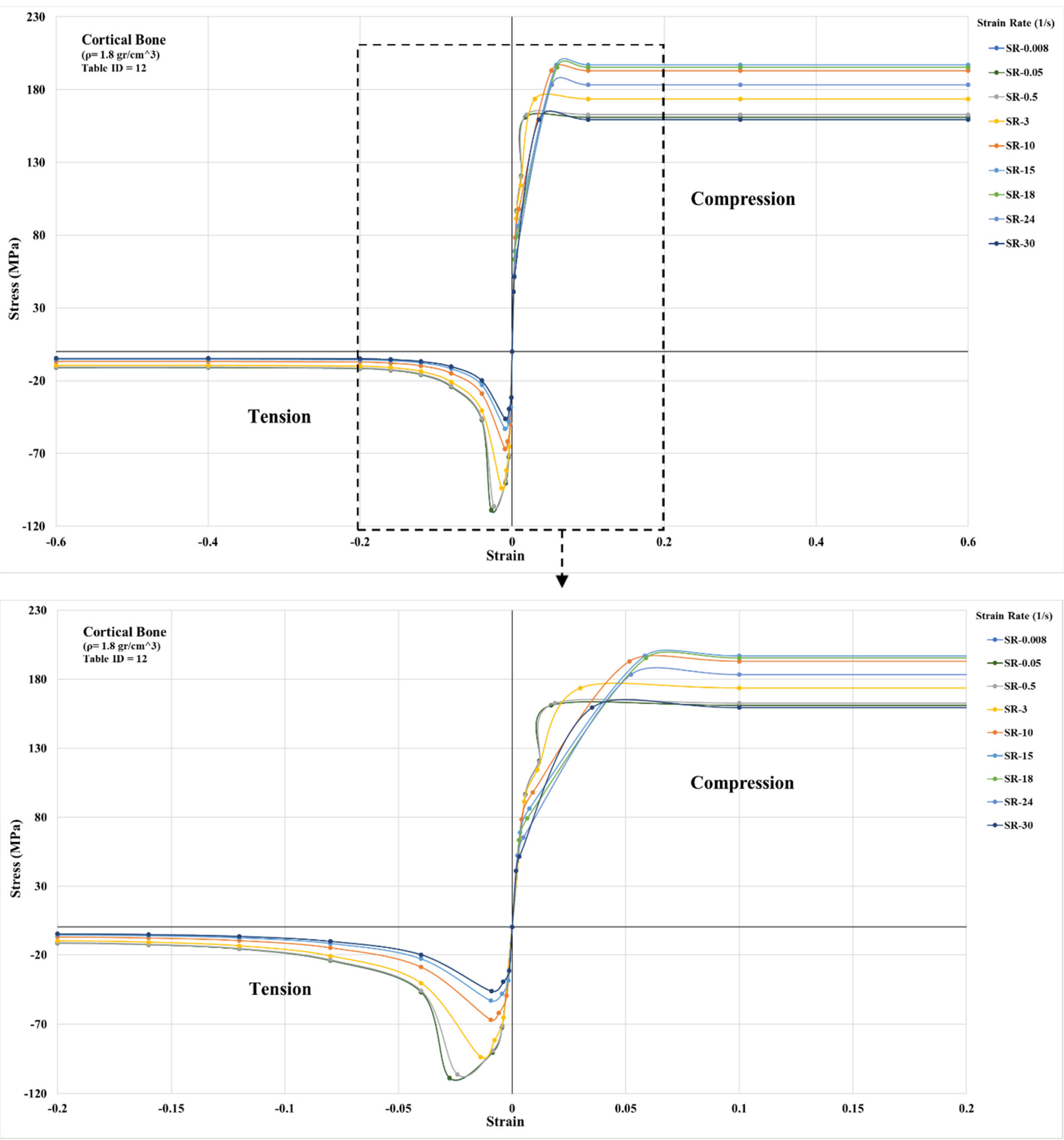

Figure A7. Cont. 


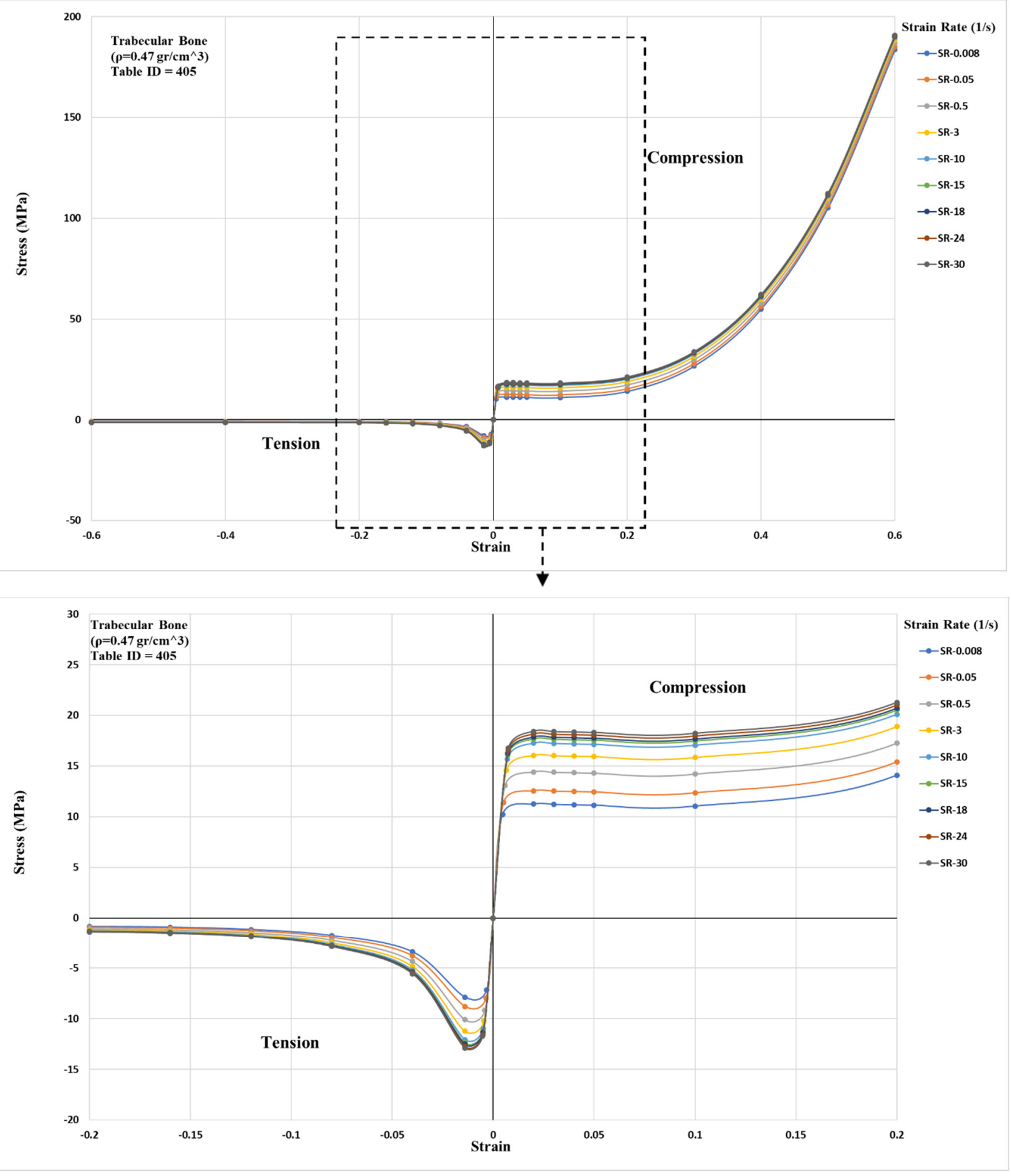

Figure A7. Cont. 


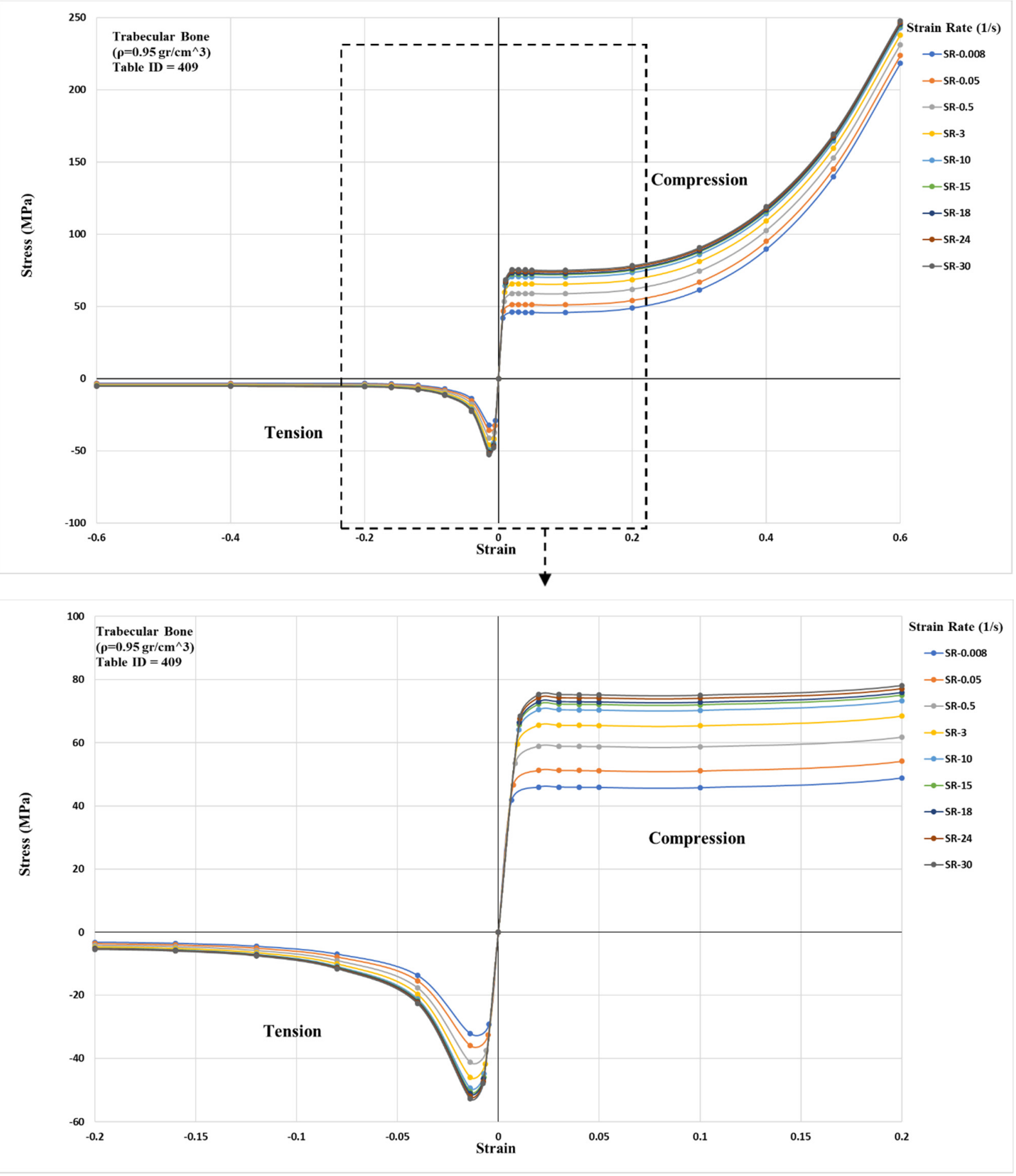

Figure A7. Cont. 

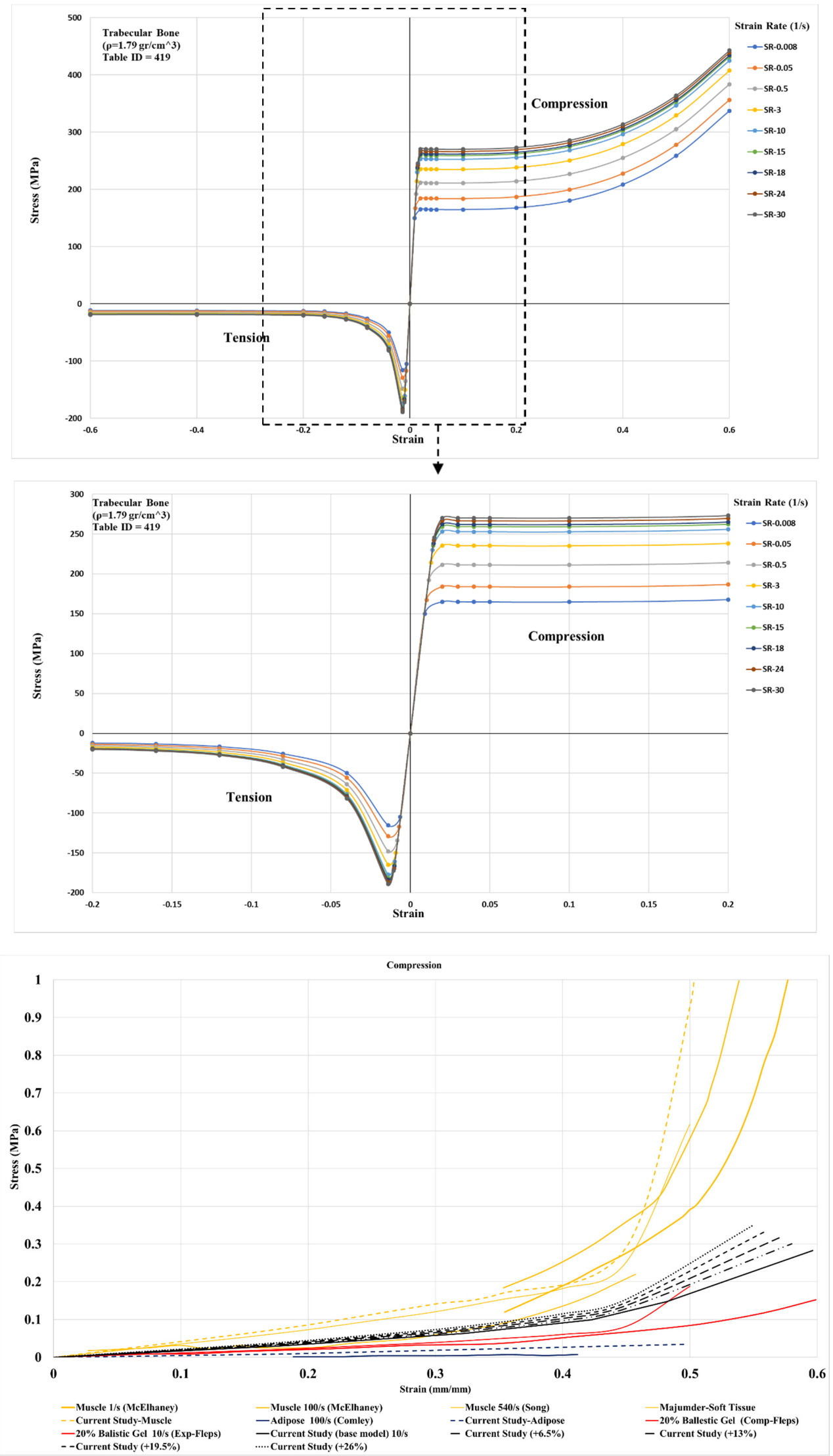

Figure A7. Stress-strain response of various experimental and computational models for the trochanteric soft tissue. 


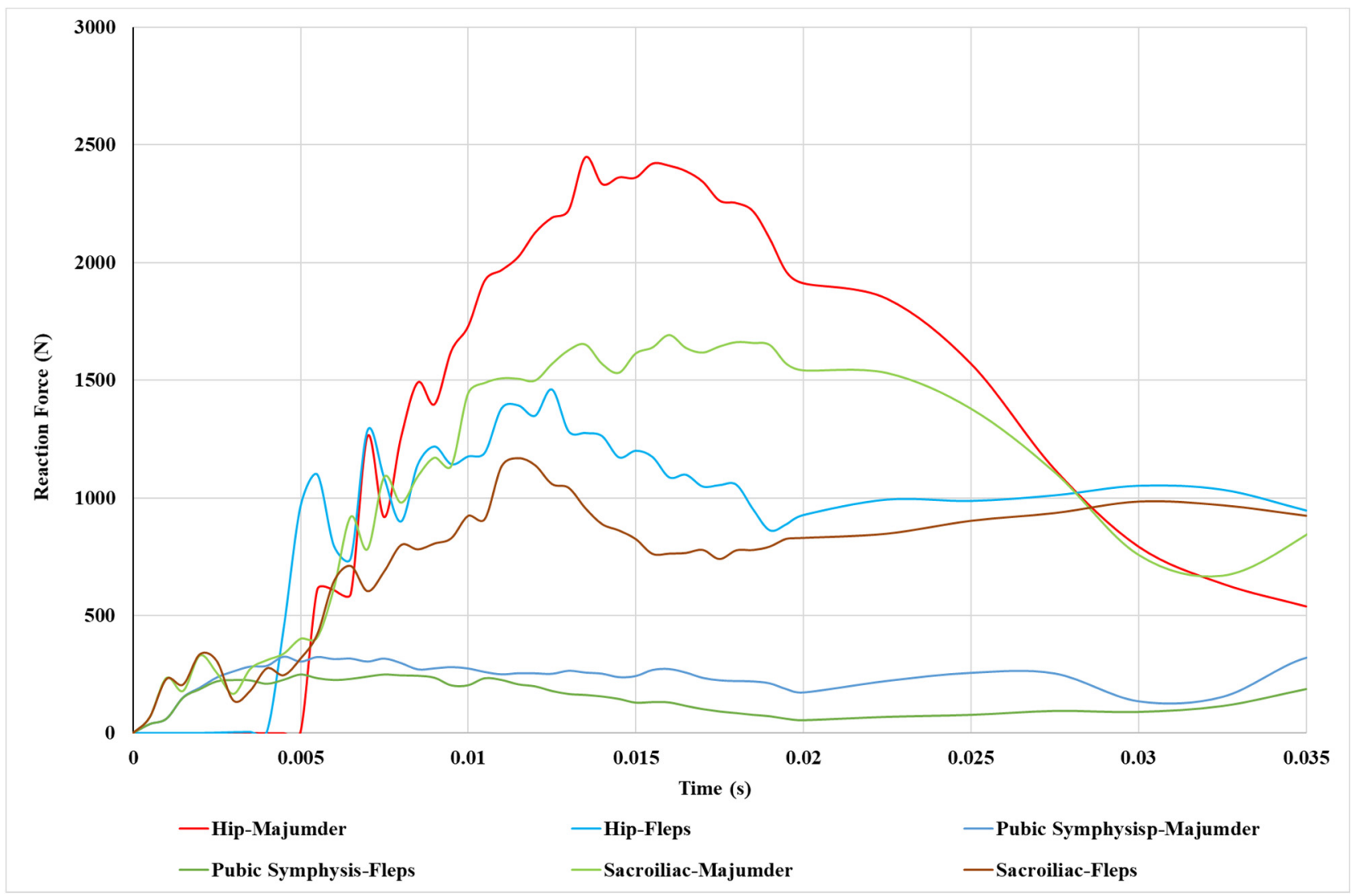

Figure A8. Internal reaction force history graphs within the joints for the trochanteric soft tissue model proposed by Majumder et al. [32] and Fleps et al. [13].

\section{References}

1. Kannus, P.; Parkkari, J.; Niemi, S.; Sievänen, H. Low-Trauma Pelvic Fractures in Elderly Finns in 1970-2013. Calcif. Tissue Int. 2015, 97, 577-580. [CrossRef] [PubMed]

2. Ferguson, T.A.; Patel, R.; Bhandari, M.; Matta, J.M. Fractures of the acetabulum in patients aged 60 years and older. J. Bone Jt. Surgery. Br. Vol. 2010, 92, 250-257. [CrossRef] [PubMed]

3. Gebre, R.K.; Hirvasniemi, J.; Lantto, I.; Saarakkala, S.; Leppilahti, J.; Jämsä, T. Structural risk factors for low-energy acetabular fractures. Bone 2019, 127, 334-342. [CrossRef] [PubMed]

4. Firoozabadi, R.; Cross, W.W.; Krieg, J.C.; Routt, M.L. “Chip” Acetabular Fractures in the Senior Population-Epidemiology, Mortality and Treatments. Arch. bone Jt. Surg. 2017, 5, 96-102. [PubMed]

5. Laird, A.; Keating, J.F. Acetabular fractures. J. Bone Jt. Surgery. Br. Vol. 2005, 87, 969-973. [CrossRef] [PubMed]

6. Letournel, R.; Judet, E. Fractures of the Acetabulum; Springer: Berlin/Heidelberg, Germany, 1981.

7. Papadakos, N.; Pearce, R.; Bircher, M.D. Low energy fractures of the acetabulum. Ann. R. Coll. Surg. Engl. 2014, 96, 297-301. [CrossRef]

8. Butterwick, D.; Papp, S.; Gofton, W.; Liew, A.; Beaulé, P.E. Acetabular Fractures in the Elderly: Evaluation and Management. J. Bone Jt. Surgery. 2015, 97, 758-768. [CrossRef]

9. Khakpour, S.; Tanska, P.; Saarakkala, S.; Korhonen, R.K.; Jämsä, T. The effect of body configuration on the strain magnitude and distribution within the acetabulum during sideways falls: A finite element approach. J. Biomech. 2021, 114, 110156. [CrossRef]

10. Robinovitch, S.N.; Hayes, W.C.; McMahon, T.A. Prediction of Femoral Impact Forces in Falls on the Hip. J. Biomech. Eng. 1991, 113, 366-374. [CrossRef]

11. Hayes, W.; Myers, E.; Robinovitch, S.; Kroonenberg, A.V.D.; Courtney, A.; McMahon, T. Etiology and prevention of age-related hip fractures. Bone 1996, 18, S77-S86. [CrossRef]

12. Levine, I.C.; Bhan, S.; Laing, A.C. The effects of body mass index and sex on impact force and effective pelvic stiffness during simulated lateral falls. Clin. Biomech. 2014, 28, 1026-1033. [CrossRef] [PubMed]

13. Fleps, I.; Enns-Bray, W.S.; Guy, P.; Ferguson, S.J.; Cripton, P.A.; Helgason, B. On the internal reaction forces, energy absorption, and fracture in the hip during simulated sideways fall impact. PLoS ONE 2018, 13, e0200952. [CrossRef] 
14. Krogue, J.D.; Cheng, K.V.; Hwang, K.M.; Toogood, P.; Meinberg, E.G.; Geiger, E.J.; Zaid, M.; McGill, K.C.; Patel, R.; Sohn, J.H.; et al. Automatic Hip Fracture Identification and Functional Subclassification with Deep Learning. Radiol. Artif. Intell. 2020, 2, e190023. [CrossRef]

15. Sarvi, M.N.; Luo, Y. Sideways fall-induced impact force and its effect on hip fracture risk: A review. Osteoporos. Int. 2017, 28, 2759-2780. [CrossRef] [PubMed]

16. Robinovitch, S.N.; Inkster, L.; Maurer, J.; Warnick, B. Strategies for Avoiding Hip Impact during Sideways Falls. J. Bone Miner. Res. 2003, 18, 1267-1273. [CrossRef] [PubMed]

17. Keyak, J.H.; Rossi, S.A.; Jones, K.A.; Skinner, H.B. Prediction of femoral fracture load using automated finite element modeling. J. Biomech. 1997, 31, 125-133. [CrossRef]

18. Smith, L.D. Hip Fractures: The Role of Muscle Contraction or Intrinsic Forces in the Causation of Fractures of the Femoral Neck. JBJS 1953, 35, 367-383. [CrossRef]

19. Khoshbin, A.; Atrey, A.; Chaudhry, H.; Nowak, L.; Melo, L.T.; Stavrakis, A.; Schemitsch, E.H.; Nauth, A. Mortality Rate of Geriatric Acetabular Fractures is High Compared to Hip Fractures. A Matched Cohort Study. J. Orthop. Trauma 2020, 34, 424-428. [CrossRef]

20. Shim, V.; Böhme, J.; Vaitl, P.; Klima, S.; Josten, C.; Anderson, I. Finite element analysis of acetabular fractures—development and validation with a synthetic pelvis. J. Biomech. 2010, 43, 1635-1639. [CrossRef]

21. Lachance, C.C.; Jurkowski, M.P.; Dymarz, A.C.; Robinovitch, S.N.; Feldman, F.; Laing, A.C.; Mackey, D.C. Compliant flooring to prevent fall-related injuries in older adults: A scoping review of biomechanical efficacy, clinical effectiveness, cost-effectiveness, and workplace safety. PLoS ONE 2017, 12, e0171652. [CrossRef]

22. Drahota, A.K.; Gal, D.L.; Windsor, J. Flooring as an intervention to reduce injuries from falls in healthcare settings: An overview. Qual. Ageing Older Adults 2007, 8, 3-9. [CrossRef]

23. Njogu, F.; Brown, P. Cost Effectiveness of Impact Absorbent Flooring in Reducing Fractures among Institutionalized Elderly; University of Auckland: Auckland, New Zealand, 2008.

24. Laing, A.C.; Robinovitch, S.N. Low stiffness floors can attenuate fall-related femoral impact forces by up to $50 \%$ without substantially impairing balance in older women. Accid. Anal. Prev. 2009, 41, 642-650. [CrossRef] [PubMed]

25. Simpson, A.H.W.R.; Lamb, S.; Roberts, P.J.; Gardner, T.N.; Evans, J.G. Does the type of flooring affect the risk of hip fracture? Age Ageing 2004, 33, 242-246. [CrossRef] [PubMed]

26. Yamin, N.A.; Amran, M.A.; Basaruddin, K.S.; Salleh, A.F.; Rusli, W.M. Ground reaction force response during running on different surface hardness. ARPN J. Eng. Appl. Sci. 2017, 12, 2313-2318.

27. Bhan, S.; Levine, I.; Laing, A.C. The Influence of Body Mass Index and Gender on the Impact Attenuation Properties of Flooring Systems. J. Appl. Biomech. 2013, 29, 731-739. [CrossRef]

28. Glinka, M.; Karakolis, T.; Callaghan, J.P.; Laing, A.C. Characterization of the protective capacity of flooring systems using force-deflection profiling. Med Eng. Phys. 2013, 35, 108-115. [CrossRef]

29. Bouxsein, M.L.; Courtney, A.C.; Hayes, W.C. Ultrasound and densitometry of the calcaneus correlate with the failure loads of cadaveric femurs. Calcif. Tissue Int. 1995, 56, 99-103. [CrossRef]

30. Meyer, H.E.; Tverdal, A.; Falch, J.A. Body height, body mass index, and fatal hip fractures: 16 years' follow-up of 674,000 Norwegian women and men. Epidemiology 1995, 6, 299-305. [CrossRef]

31. Bouxsein, M.L.; Szulc, P.; Munoz, F.; Thrall, E.; Delmas, P.D.; Sornay-Rendu, E. Contribution of Trochanteric Soft Tissues to Fall Force Estimates, the Factor of Risk, and Prediction of Hip Fracture Risk. J. Bone Miner. Res. 2007, 22, 825-831. [CrossRef]

32. Majumder, S.; Roychowdhury, A.; Pal, S. Effects of trochanteric soft tissue thickness and hip impact velocity on hip fracture in sideways fall through 3D finite element simulations. J. Biomech. 2008, 41, 2834-2842. [CrossRef]

33. Majumder, S.; Chowdhury, A.R.; Pal, S. Three-dimensional finite element simulation of pelvic fracture during side impact with pelvis-femur-soft tissue complex. Int. J. Crashworthiness 2008, 13, 313-329. [CrossRef]

34. Choi, W.; Russell, C.; Tsai, C.; Arzanpour, S.; Robinovitch, S. Age-related changes in dynamic compressive properties of trochanteric soft tissues over the hip. J. Biomech. 2015, 48, 695-700. [CrossRef] [PubMed]

35. Fleps, I.; Fung, A.; Guy, P.; Ferguson, S.J.; Helgason, B.; Cripton, P.A. Subject-specific ex vivo simulations for hip fracture risk assessment in sideways falls. Bone 2019, 125, 36-45. [CrossRef] [PubMed]

36. Enns-Bray, W.; Bahaloo, H.; Fleps, I.; Ariza, O.; Gilchrist, S.; Widmer, R.; Guy, P.; Pálsson, H.; Ferguson, S.; Cripton, P.; et al. Material mapping strategy to improve the predicted response of the proximal femur to a sideways fall impact. J. Mech. Behav. Biomed. Mater. 2018, 78, 196-205. [CrossRef]

37. Robinson, D.L.; Kersh, M.E.; Walsh, N.C.; Ackland, D.C.; De Steiger, R.N.; Pandy, M.G. Mechanical properties of normal and osteoarthritic human articular cartilage. J. Mech. Behav. Biomed. Mater. 2016, 61, 96-109. [CrossRef]

38. Li, Z.; Alonso, J.E.; Kim, J.-E.; Davidson, J.S.; Etheridge, B.S.; Eberhardt, A.W. Three-Dimensional Finite Element Models of the Human Pubic Symphysis with Viscohyperelastic Soft Tissues. Ann. Biomed. Eng. 2006, 34, 1452-1462. [CrossRef]

39. Du, W.; Zhang, J.; Hu, J. Method to Determine Cortical Bone Thickness of Human Femur and Tibia using Clinical CT Scans. In Proceedings of the International Research Council on the Biomechanics of Injury, IRCOBI, Athens, Greece; 2018 ; pp. 388-398.

40. Giudice, J.S.; Poulard, D.; Nie, B.; Wu, T.; Panzer, M.B. A Cortical Thickness Mapping Method for the Coxal Bone Using Morphing. Front. Bioeng. Biotechnol. 2018, 6, 1-9. [CrossRef] 
41. Khanal, L.; Shah, S.; Koirala, S. Estimation of Total Length of Femur from its Proximal and Distal Segmental Measurements of Disarticulated Femur Bones of Nepalese Population using Regression Equation Method. J. Clin. Diagn. Res. 2017, 11, HC01-HC05. [CrossRef]

42. Human Biodigital ${ }^{\circledR}$ Online Platform. 2020. Available online: https:/ /www.biodigital.com/ (accessed on 25 March 2020).

43. Mechlenburg, I.; Nyengaard, J.; Gelineck, J.; Soballe, K. Cartilage thickness in the hip joint measured by MRI and stereologyA methodological study. Osteoarthr. Cartil. 2007, 15, 366-371. [CrossRef]

44. Zheng, N.; Watson, L.G.; Yong-Hing, K. Biomechanical modelling of the human sacroiliac joint. Med Biol. Eng. Comput. 1997, 35, 77-82. [CrossRef]

45. Majumder, S.; Chowdhury, A.R.; Pal, S. Simulation of hip fracture in sideways fall using a 3D finite element model of pelvisfemur-soft tissue complex with simplified representation of whole body. Med Eng. Phys. 2007, 29, 1167-1178. [CrossRef] [PubMed]

46. Contini, R. Body Segment Parameters, Part II, Artificial Limbs. 1972. Available online: http://www.oandplibrary.org/al/pdf/19 72_01_001.pdf (accessed on 11 February 2020).

47. Nigam, S.P.; Malik, M. A Study on a Vibratory Model of a Human Body. J. Biomech. Eng. 1987, 109, 148-153. [CrossRef]

48. Amirouche, F.M.L. Modeling of Human Reactions to Whole-Body Vibration. J. Biomech. Eng. 1987, 109, 210-217. [CrossRef] [PubMed]

49. Hansen, U.; Zioupos, P.; Simpson, R.; Currey, J.D.; Hynd, D. The Effect of Strain Rate on the Mechanical Properties of Human Cortical Bone. J. Biomech. Eng. 2008, 130, 011011. [CrossRef] [PubMed]

50. Lim, K.; Choi, W. Soft tissue stiffness over the hip increases with age and its implication in hip fracture risk in older adults. J. Biomech. 2019, 93, 28-33. [CrossRef]

51. Bandak, F.; Tannous, R.; Toridis, T. On the development of an osseo-ligamentous finite element model of the human ankle joint. Int. J. Solids Struct. 2001, 38, 1681-1697. [CrossRef]

52. Robinson, J. A single element test. Comput. Methods Appl. Mech. Eng. 1976, 7, 191-200. [CrossRef]

53. Li, Z.; Kim, J.-E.; Davidson, J.S.; Etheridge, B.S.; Alonso, J.E.; Eberhardt, A.W. Biomechanical response of the pubic symphysis in lateral pelvic impacts: A finite element study. J. Biomech. 2007, 40, 2758-2766. [CrossRef]

54. Xiao, Y.; Wu, H.; Ping, X. On the Simulation of Fragmentation During the Process of Ceramic Tile Impacted by Blunt Projectile with SPH Method in LS-DYNA. Comput. Model. Eng. Sci. 2020, 122, 923-954. [CrossRef]

55. Li, H.; Yu, C.; Chen, R.; Li, J.; Li, J. Novel ionic liquid-type Gemini surfactants: Synthesis, surface property and antimicrobial activity. Colloids Surfaces A Physicochem. Eng. Asp. 2012, 395, 116-124. [CrossRef]

56. Meyer, F.; Deck, C.; Willinger, R.; Meyer, P. Development of a 3-year-old child head-neck finite element model and derivation of novel head injury criterion. Int. J. Crashworthiness 2013, 19, 233-243. [CrossRef]

57. Otkur, M. Impact Modeling and Failure Modes of Composite Plywood; Texas Tech University: Lubbock, TX, USA, 2010.

58. De Almeida, C. Mechanical Behaviour of Complex Structures under High Speed Impacts; Téecnico Lisboa: Lisboa, Portugal, 2016.

59. Murray, Y. Users Manual for LS-DYNA Concrete Material Model 159; Federal Highway Administration, Office of Research, Development, and Technology: McLean, VA, USA, 2007.

60. Xiangguo, Z.; Guowei, Z.; Xu, W. Finite Element Analysis of Asphalt Pavement under Projectile Impact Load. IOP Conf. Ser. Mater. Sci. Eng. 2019, 631, 022022. [CrossRef]

61. Clarke, S.G.; Phillips, A.T.M.; Bull, A.M.J. Evaluating a suitable level of model complexity for finite element analysis of the intact acetabulum. Comput. Methods Biomech. Biomed. Eng. 2013, 16, 717-724. [CrossRef] [PubMed]

62. Hewitt, J.D.; Glisson, R.R.; Guilak, F.; Vail, T. The mechanical properties of the human hip capsule ligaments. J. Arthroplast. 2002, 17, 82-89. [CrossRef]

63. Silvestri, C. Development and Validation of A Knee-Thigh-Hip Lsdyna Model of A 50th Percentile Male; Worcester Polytechnic Institute: Worcester, MA, USA, 2008.

64. Luo, Y.; Sarvi, M.N. A subject-specific inverse-dynamics approach for estimating joint stiffness in sideways fall. Int. J. Exp. Comput. Biomech. 2015, 3, 137. [CrossRef]

65. Feldman, F.; Robinovitch, S.N. Reducing hip fracture risk during sideways falls: Evidence in young adults of the protective effects of impact to the hands and stepping. J. Biomech. 2007, 40, 2612-2618. [CrossRef]

66. Livermore Software Technology Corporation, LS-DYNA Keyword User's Manual Volume II R7.1, 1st ed.; LSTC: California, CA, USA, 2014.

67. Lemmon, D.; Shiang, T.; Hashmi, A.; Ulbrecht, J.S.; Cavanagh, P.R. The effect of insoles in therapeutic footwear-A finite element approach. J. Biomech. 1997, 30, 615-620. [CrossRef]

68. Noor, V. Skin Friction a Novel Approach to Measuring In Vivo Human Skin; University of Twente: Enschede, The Netherlands, 2013.

69. Leguillon, D. Strength or toughness? A criterion for crack onset at a notch. Eur. J. Mech. A/Solids 2002, 21, 61-72. [CrossRef]

70. Doitrand, A.; Martin, E.; Leguillon, D. Numerical implementation of the coupled criterion: Matched asymptotic and full finite element approaches. Finite Elements Anal. Des. 2020, 168, 103344. [CrossRef]

71. Helgason, B.; Gilchrist, S.; Ariza, O.; Chak, J.; Zheng, G.; Widmer, R.; Ferguson, S.; Guy, P.; Cripton, P. Development of a balanced experimental-computational approach to understanding the mechanics of proximal femur fractures. Med Eng. Phys. 2014, 36, 793-799. [CrossRef]

72. Majumder, S.; Roychowdhury, A.; Pal, S. Hip fracture and anthropometric variations: Dominance among trochanteric soft tissue thickness, body height and body weight during sideways fall. Clin. Biomech. 2013, 28, 1034-1040. [CrossRef] [PubMed] 
73. Sarvi, M.N.; Luo, Y.; Sun, P.; Ouyang, J. Experimental Validation of Subject-Specific Dynamics Model for Predicting Impact Force in Sideways Fall. J. Biomed. Sci. Eng. 2014, 7, 405-418. [CrossRef]

74. Bala, S. Overview of Mass-Scaling in LS-DYNA. 2006. Available online: http://blog.d3view.com/?p=2064 (accessed on 17 March 2020).

75. Askarinejad, S.; Johnson, J.E.; Rahbar, N.; Troy, K.L. Effects of loading rate on the of mechanical behavior of the femur in falling condition. J. Mech. Behav. Biomed. Mater. 2019, 96, 269-278. [CrossRef] [PubMed]

76. Opotowsky, A.R.; Su, B.W.; Bilezikian, J.P. Height and Lower Extremity Length as Predictors of Hip Fracture: Results of the NHANES I Epidemiologic Follow-up Study. J. Bone Miner. Res. 2003, 18, 1674-1681. [CrossRef] [PubMed]

77. Bouquet, R.; Ramet, M.; Bermond, F.; Caire, Y.; Talantikite, Y.; Robin, S.; Voiglio, E. Pelvis Human response to Lateral Impact. In Proceedings of the 16th Enhanced Safety of Vehicles conference, Windsor, ON, Canada, 31 May-4 June 1998.

78. Ural, A.; Zioupos, P.; Buchanan, D.; Vashishth, D. The effect of strain rate on fracture toughness of human cortical bone: A finite element study. J. Mech. Behav. Biomed. Mater. 2011, 4, 1021-1032. [CrossRef] [PubMed]

79. Cecil, A.; Yu, J.W.; Rodriguez, V.A.; Sima, A.; Torbert, J.; Satpathy, J.; Perdue, P.; Toney, C.; Kates, S. High- Versus Low-Energy Acetabular Fracture Outcomes in the Geriatric Population. Geriatr. Orthop. Surg. Rehabil. 2020, 11, 1-6. [CrossRef]

80. Pagenkopf, E.; Grose, A.; Partal, G.; Helfet, D. Acetabular Fractures in the Elderly: Treatment Recommendations. HSS J. 2006, 2,161-171. [CrossRef]

81. Letournel, E.; Judet, R. Fractures of the Acetabulum, 2nd ed.; Springer: Berlin/Heidelberg, Germany, 1993.

82. Kroonenberg, A.J.V.D.; Hayes, W.C.; McMahon, T.A. Hip impact velocities and body configurations for voluntary falls from standing height. J. Biomech. 1996, 29, 807-811. [CrossRef]

83. Rinne, P.P.; Laitinen, M.K.; Huttunen, T.; Kannus, P.; Mattila, V.M. The incidence and trauma mechanisms of acetabular fractures: A nationwide study in Finland between 1997 and 2014. Inj. 2017, 48, 2157-2161. [CrossRef]

84. Keenan, B.E.; Hallas, K.; Drahota, A.K.; Evans, S.L. A comparison of floor surfaces for injury prevention in care settings: Impact forces and horizontal pulling force required to move wheeled equipment. Osteoporos. Int. 2020, 31, 2383-2394. [CrossRef]

85. Blake, S.P.; Connors, A.M. Sacral insufficiency fracture. Br. J. Radiol. 2004, 77, 891-896. [CrossRef] [PubMed]

86. Papanicolaou, G.; Zaoutsos, S. Viscoelastic constitutive modeling of creep and stress relaxation in polymers and polymer matrix composites. In Creep and Fatigue in Polymer Matrix Composites; Woodhead Publishing: Cambridge, UK, 2019; pp. 3-59. [CrossRef]

87. Guo, X.E.; Kim, C. Mechanical consequence of trabecular bone loss and its treatment: A three-dimensional model simulation. Bone 2002, 30, 404-411. [CrossRef]

88. Robinovitch, S.N.; Hayes, W.; McMahon, T.A. Predicting the Impact Response of a Nonlinear Single-Degree-of-Freedom ShockAbsorbing System From the Measured Step Response. J. Biomech. Eng. 1997, 119, 221-227. [CrossRef] [PubMed]

89. Kroonenberg, A.J.V.D.; Hayes, W.C.; McMahon, T.A. Dynamic Models for Sideways Falls From Standing Height. J. Biomech. Eng. 1995, 117, 309-318. [CrossRef] [PubMed] 